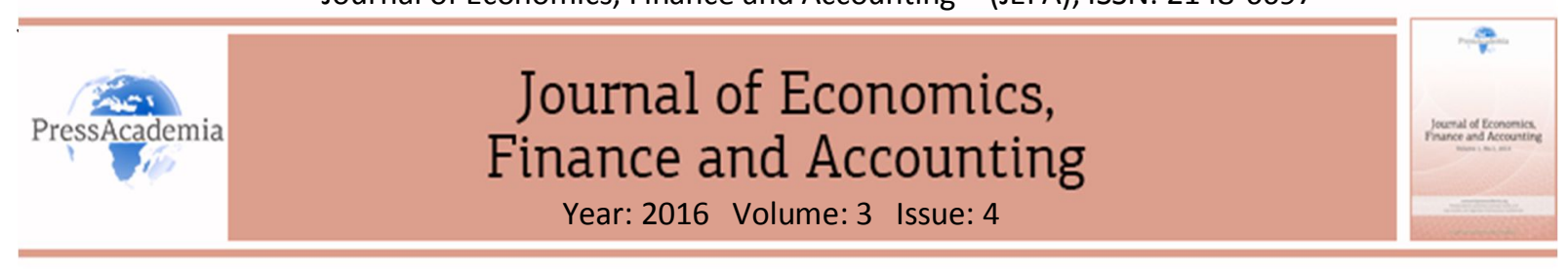

\title{
ANALYSIS OF DEVELOPED AND DEVELOPING COUNTRIES GROUPS THE MACRO-ECONOMIC FACTORS WHICH ARE AFFECTED BY FINACIAL INDICATORS: 2000-2012
}

\section{DOI: 10.17261/Pressacademia.2016.345}

\author{
Selahattin Koc ${ }^{1}$, Zekai Senol ${ }^{2}$, Suleyman Serdar Karaca ${ }^{3}$ \\ ${ }^{1}$ Cumhuriyet Üniversitesi. skoc@cumhuriyet.edu.tr \\ ${ }^{2}$ Cumhuriyet Üniversitesi.zzsenol@cumhuriyet.edu.tr \\ ${ }^{3}$ Gaziosmanpaşa Üniversitesi. suleymanserdar.karaca@gop.edu.tr
}

\section{ABSTRACT}

One of the major factors affecting the development of the countries is their financial system being advanced and working efficiently. Because financial development indicator affect investments directly, it is a key variable that countries need to strong. In this paper macro-economics factors affecting financial development indicators have been analyzed for two groups of countries, which are the developed countries of Canada, France, Germany, Japan, Britain and the USA and the developing countries of Brazil, China, India, Malaysia, Russia Federation and Turkey by the comparative Panel Data Analysis. According to the analysis, interest rate and eceonomic growth, which are the macroeconomics variables, are the factors that most affect the financial development for both country groups. In addition there is no significant difference in term of other macro-economic variable for both country groups. The Granger Causality tests have been found to support the panel regression results.
\end{abstract}

Keywords: Financial development indicators, macroeconomic factors, panel data analysis, Granger Causality. JEL Classification: C33, E6, E44, G20, F62

\section{FiNANSAL GELIŞMIŞLiĞi ETKILEYEN MAKROEKONOMIK FAKTÖRLERIN GELIŞMIŞ VE GELIŞMEKTE OLAN ÜLKELER ÖRNEKLEMINDE ANALIZI: 2000-2012}

\section{ÖZET}

Ülkelerin kalkınmasına etki eden önemli kalemlerden birisi de gelişmiş ve verimli olarak işleyen finansal sistemlerdir. Finansal gelişmişlik göstergeleri doğrudan yapılan yatıımları etkileyen temel değişken olarak alındığından her ülkenin etkinlik sağlamak istediği önemli göstergelerdir. Bu çalışmada, Kanada, Fransa, Almanya, Japonya, İngiltere ve Amerika'dan oluşan geliş̧miş ülkeler ile Brezilya, Çin, Hindistan, Malezya, Rusya Federasyonu ve Türkiye'nin oluşturduğu gelişmekte olan ülkelerin, finansal gelişmişlik göstergelerini etkileyen makro faktörlerinin karşılaşıırmalı olarak Panel Veri Analizi değerlendirilmesi yapılmıştır. Yapılan analize göre, makro ekonomik değişkenlerden faiz oranları ve ekonomik büyümenin her iki ülke grubu içinde finansal gelişmişliği en fazla etkileyen değişkenler olduğu, makro ekonomik değişkenler bakımından iki ülke grubu arasında belirgin farklıııların olmadığı görülmüştür. Granger Nedensellik testleri ise, panel regresyon sonuçlarını desteklediği tespit edilmiş̧ir.

Anahtar Kelimeler: Finansal gelişmişlik göstergeleri, makroekonomik faktörler, panel veri analizi, Granger Nedensellik. JEL Sınıflandırması: C33, E6, E44, G20, F62 


\section{GiRiş}

Finansal gelişmişlik, finansal piyasalarda faaliyette bulunan kurumların sayılarının artması, finansal araçların çeşitliliklerinin çoğalması, yaygınlaşması, finansal piyasaların derinleşmesi ve bunlara bağlı olarak finansal piyasaların temel fonksiyonu olan fon aktarımının yerine getirilmesidir.

Finansal gelişmişlik ile makro değişkenler arasındaki çalışmalara bakıldığında çok eskilere kadar gittiği görülmektedir. Özellikle finansal gelişme-büyüme, borç-ekonomik büyüme arasındaki yapılan çalışmalar çok daha eskilere gitmektedir. Bagehot (1873) İngiltere'de iyi organize edilmiş sermaye piyasalarının, piyasada oluşan fonların daha verimli yatırımlara tahsis edilmesine katkı sağladığını ifade etmiştir. Schumpeter (1911), Hicks (1969) and Goldsmith (1969), finansal piyasaların gelişmesinin genel olarak ekonomiye pozitif olarak yansıdığını ileri sürmüşlerdir (Huang, 2010).

1929 Dünya Ekonomik bunalımı sonrası öne çıkan devletçilik uygulamalarının enflasyon artırıcı bulunmasından sonra 1974 krizinden sonra bir çok ülkede kalkınma hamlelerini başlatmak üzere finansal liberalleşme politikaları uygulanmaya başlanmıştır. Gelişmekte olan her ülke hatta gelişmiş ülkeler de dahil olmak üzere yabancı sermayeyi kendi ülkelerine gelmesini sağlamak amacıyla makro düzeyde bir çok düzenlemeye gidilmiştir. Geçmiş çalışmalara bakıldığında yoğunlaşmanın finansal gelişmişlik düzeyleri ile ekonomik büyüme arasındaki ilişkileri araştıran çalışmalarda olduğu görülmektedir. Büyüme, makro değişkenlerden yalnızca biridir. 1911(Schumpeter ) ile başlayan finansal gelişmişlik ve büyüme üzerine araştırmalar McKinnon (1973) ve Shaw (1973) ile devam etmiştir. Son zamanlarda ise bu konu ile ilgili çalışmaların daha da arttığı gözlenmektedir. Bu konuda yapılan çalışmaların artmasının nedeni, ülkeler finansal gelişmişlik göstergeleri ile makro değişkenler arasındaki nedenselliklere bakarak politikalar geliştirmek istemeleridir.

Finansal gelişme ve büyüme ilişkisi Patrick (1966)'da ise arz yönlü ve talep yönlü yaklaşımlar çerçevesinde analiz edilmiştir. Arz yönlü yaklaşım; piyasa liberalizasyonu sonucu finansal piyasaların gelişmesi ve çeşitlenmesinin tasarrufların yatırımlara dönüşme sürecini hızlandırdığı ve ekonomik büyümeyi artırdığı temeline dayanır. Talep yönlü yaklaşım ise, finansal gelişmenin büyüme sürecinde önemli bir rolü olmadığı noktasından hareket etmektedir (Ceylan ve Durkaya, 2010).

Finansal gelişmişlik göstergeleri ile pay senetleri arasındaki ilişkinin araştırıldığı çalışmalara bakıldığında ise, (King ve Levine, 1993; Arestis ve Demetriades, 1997; Thiel, 2001; Kar, 2001; Eschenbach, 2004; Lawrence, 2006; Shan ve Jianhong, 2006; Ang, 2007; Doğan, 2008; Öztürk, 2008) genel olarak iyi işleyen bir hisse senedi piyasası, finans sektörünün temel unsuru olarak görülmektedir ve iyi işleyen finansal kurumların ve hisse senedi piyasasının gelişmesinin sürdürülebilir ekonomik büyümeyi gerçekleştirmede kritik bir rol oynadığı savunulmaktadır (Ayaydın ve diğ. 2013).

Son yıllarda ivme kazanan küreselleşme hareketleri sonrası finansal piyasaların gelişmesi, serbestleşmesi ve alt piyasalardaki etkileşimin derecesinin artması sonucunda menkul kıymetlerin fiyatları ekonomik gelişmelere karşı aşırı duyarlı hale gelmiştir. Yaşanan küreselleşme hareketleri ile birlikte, ülkelerin ekonomik gelişmişlik düzeyine ilişkin en önemli göstergelerden birisi gelişmiş finansal piyasaların varlığı olmuştur (Akıncı ve diğ., 2014). Gelişmiş bir finansal piyasadan bahsedebilmemiz için finansal kurumların ve hizmet çeşitliliğinin arttırıldığı bir ekonomik yapının olmasını, finansal kesimlerce yaratılan fonların reel kesime aktarılma oranlarının yüksek olması gerektiğini vurgulamak gerekir (Ağır, 2010: 89).

Finansal piyasalar ve kurumların gelişmesinin, ekonomik gelişme sürecinde çok önemli görevler üstlendiklerine dair teorik ve ampirik bir çok yazın bulunmaktadır (King ve Levine, 1993a, 1993b; Arestis ve Demetriades, 1997; Thiel, 2001; Eschenbach, 2004; Lawrence, 2006; Shan ve Jianhong, 2006; Ang, 2007; Jalilian ve Kirkpatrick, 2002; Calderon ve Liu, 2002; Beck ve Levine, 2004). Ampirik çalışmalarda, genel olarak iyi işleyen finansal kurumların ve piyasaların uzun dönemde ekonomik büyümeye katkı yapacağına ilişkin bir uzlaşma bulunmaktadır (Ağır ve diğ, 2009). 


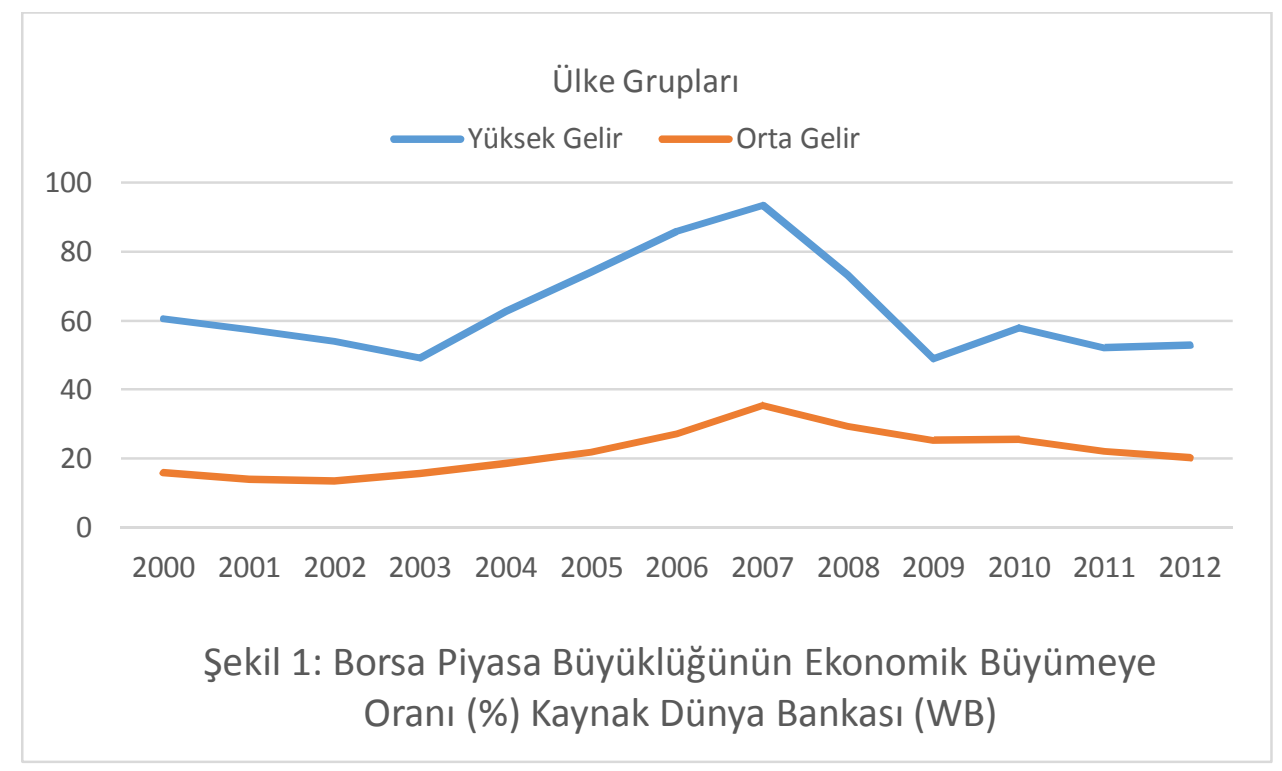

Şekil 1'e göre; borsa piyasa değerlerinin ekonomik büyümeye oranının, yüksek gelirli ülkelerde daha büyük olduğu ancak, gelişme trendi açısından orta gelirli ülke gruplarının, bu konuda küçük de olsa gelişme gösterirken, yüksek gelir grubu ülkelerinde aksine az da olsa gerileme gözlemlenmektedir. Ayrıca küresel krizden yüksek gelir grubu ülkelerinin daha fazla etkilendikleri görülmektedir.

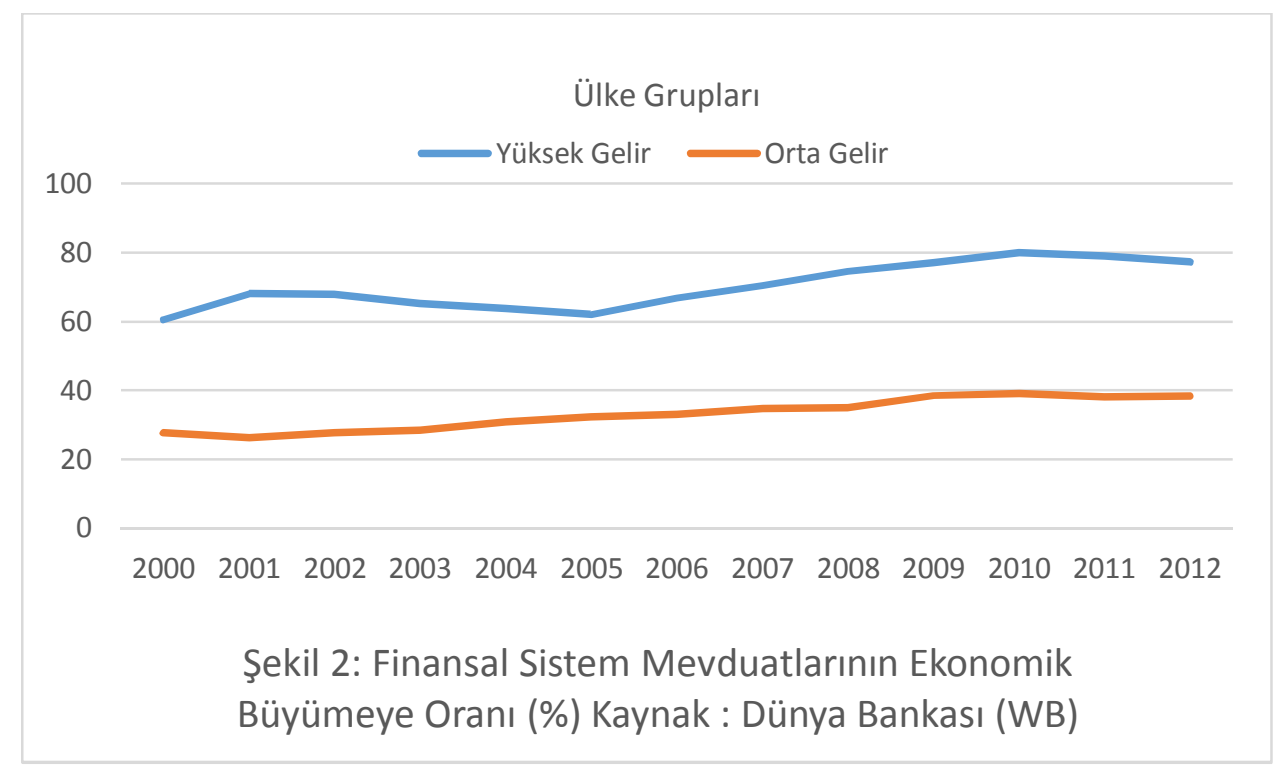

Şekil 2'de, finansal sistem mevduatlarının ekonomik büyümeye oranının, yüksek gelir grubu ülkelerde 2002 2005 döneminde az da olsa azalma gösterdiğini, her iki ülke grubu açısından baz alınan dönem açısından arttığını göstermektedir. Şekil 1 ve Şekil 2'yi birlikte değerlendirdiğimizde finansal gelişmişliği gösteren iki değişkenden borsa piyasa büyüklüğünün finansal sistem mevduatlarına göre, ekonomik koşulardan daha fazla etkilendiği görülmektedir. Bunun sebebi olarak, borsanın mevduatlara göre ekonomik koşullara daha fazla reaksiyon göstermiş olduğu söylenebilir.

Finansal gelişmişlik göstergelerinin makro ekonomik göstergeleri üç değişik şekilde etkilediği ifade edilmektedir (Zaman ve diğ, 2012). (i) risklerin paylaşımasına bağlı olarak tüm yatırım fırsatlarını değerlendiriliyor olmasından dolayı, marjinal verimliliğin artmasını sağlar, (ii) finansal aracılar tarafından çekilen tutarların azalmasını sağlayarak ve finansal aracıların etkinlikleri artırarak yatırımların artması sağlar ve (iii) özel tasarrufların artmasını sağlamaktadır. 
Finansal gelişmişlik göstergeleri ile makro değişkenler arasındaki ilişkinin incelendiği bu çalışmada makro ekonomik faktörler çerçevelendirilirken, finansal gelişmiş üzerinde yerinin belirlenmesi, daha sonraki süreçte geliştirilecek ekonomik-politik yapılanmalar açısından önem arzetmektedir. Genelikle finansal gelişmişlik göstergelerine makro ekonomik yapı içerisinde rol ya da roller biçilmektedir. Makro ekonomik yapıda sağlanan pozitif gelişmelerin finansal gelişmişlik göstergeleri üzerinde etkisi de pozitif olabileceği gibi, finansal gelişmişlik göstergelerindeki değişim de makro ekonomik faktörler üzerinde pozitif yönde etkileri olabilecektir (Ağır, 2010: 47).

Çalışmaların çoğunluğunda finansal gelişmişlik göstergelerinin makro ekonomik faktörler özellikle de büyüme üzerinde etkisinin çok fazla abartıldığını yazan yazarlar da bulunmaktadır. Lucas (1988), finansal gelişmişlik göstergelerinin büyüme üzerindeki etkisinin fazlaca abartıldığını ifade etmiştir. Singh (1997), finansal faktörlerin gelişmesiyle birlikte piyasalardaki dalgalanmaların da arttığı, buna bağlı olarak da riskten kaçınan yatırımcılar için artan riskin caydırıcı olabileceğini belirtmektedir. Mauro (1995), finansal araçların yatırımcılar tarafından bilinirliğinin artması ve bazı yatırım araçlarının da yatırımcılara korunma imkanı oluşturmalarından dolayı tasarrufların azalmasına neden olabileceğini belitmiş; tasarrufların azalması ile birlikte ekonomik büyümenin de bundan olumsuz etkileneceğini ileri sürmüştür (Ang ve McKibbin, 2005). Ayrıca (Achy, 2004; Chang, 2002; Acaravcı ve diğ., 2009; Akçoraoğlu, 2000) finansal gelişmişlik göstergelerinin ekonomik büyüme üzerinde olumlu bir etkisinin olmadığını ifade etmişlerdir.

Allen ve Gale (1999, 2000), Hellman vd. (2000), Schneider ve Tornell (2004), finansal liberalleşmenin bankaların riskli davranışlarına yol açtığını ileri sürmektedirler. Tornell and Westermann (2005), yapmış oldukları çalışmalarında finansal serbestleşmenin aşırı borç artışına/azalışına neden olacağını ve bunun finansal piyasalardaki uyumu bozacağını belirtmişlerdir. Allen ve Gale (2000), aşırı finansal serbestleşmenin borsalarda aşırı davranışların ve bankalardan kullanılacak kredilerin artışı ile piyasalarda balonların oluşmasına neden olabileceğini ileri sürmüşler.

Doğrudan yabancı sermaye yatırımları ile ekonomik büyüme arasındaki 2000 - 2013 yıllarına ait ilişki aşağıdaki şekilde görülmektedir.

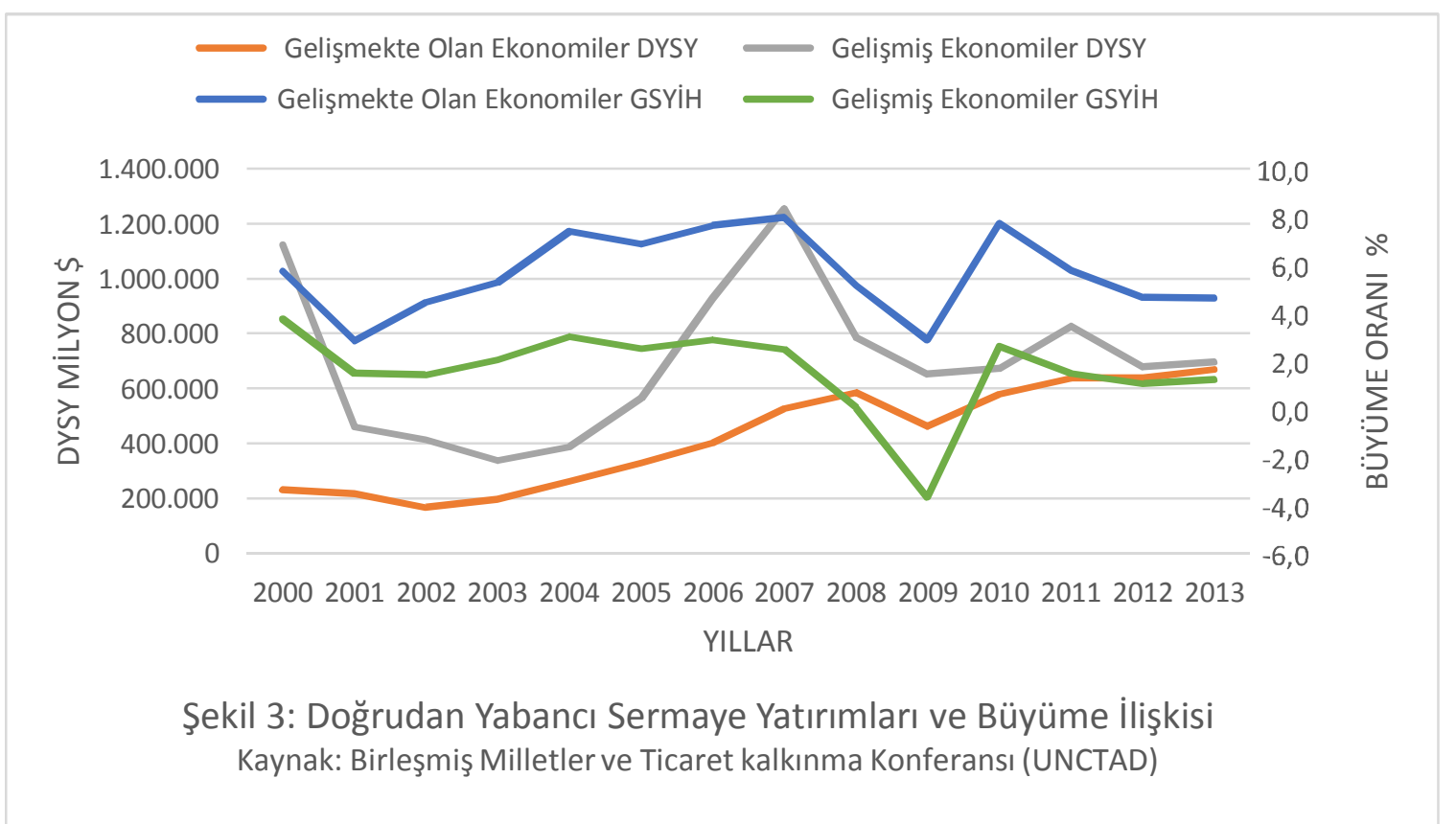

Şekil 3'e göre, gelişmekte olan ekonomilere yönelen DYSY'nın yükselen bir eğilime sahip olduğu ve gelişmiş ekonomiler düzeyine ulaştığı, buna karşın gelişmiş ekonomilerde ise DYSY'nın büyük dalgalanmalar gösterdiği ve 2000'li yıllara göre 2010'lu yıllarda azalma gösterdiği; ekonomik büyümede ise, gelişmekte olan ekonomilerin performansının gelişmiş ekonomilere göre daha iyi olduğu bu performanta DYSY'nın da etkisinin olabileceği söylenebilir. 


\section{FINANSAL SEKTÖRLERIN GELIŞIM SÜREÇLERi}

Finansal gelişmenin belirleyicileri olarak geçmiş yıllarda yapılan çalışmalarda kurumsal faktörlerde dahil olmak üzere, makro ekonomik ve coğrafi faktörlerin dikkate alındığı görülmektedir (Huang, 2010). Finansal sektörün gelişmesi, hem gelişmiş ülkelerde, hem de gelişen ekonomilerde ve piyasalarda, ekonomik büyümeyi artıran, yoksulluğu azaltan özel sektörün bir parçası niteliğindedir. Finansal sektör; kurumlar, enstrümanlar ve piyasalardan oluşan bir bütündür. Finansal gelişmişliği etkileyebilecek faktörleri aşağıdaki başlıklarla ifade edebilmek mümkündür.

\subsection{Kurumsal Yapılanmalar}

Ekonomik krizler ile finansal liberalleşmeler arasındaki ilişkiler, akademisyenler ve saha çalışanları arasında tartışmalara neden olmaktadır. Finansal liberalleşmenin krizlere ve sorunlara neden olduğu savunulduğu gibi, tam tersi görüşü de savunanlar bulunmaktadır. Rodrik (1998) ve Stiglitz (2000), sınırsız sermaye akımlarının finansal gelişme ve ekonomik büyüme üzerinde yıkıcı etkilerinin olduğunu ileri sürmüşlerdir. Bunlar, finansal küreselleşmesinin ve sermayenin serbest dolaşımının sorgulanması gerektiğini savunmuşlardır. Farklı görüşleri savunan yazarların ve piyasa çalışanlarının anlaştıkları konu, krizler ve finansal gelişme/serbestleşme üzerinde en fazla olumsuz etkiye zayıf kurumsal yönetim ve kamu yönetimi ile hükümet politikalarının yetersizliği ve etkin olmayan kurumların varlığıdır (Kaminsky ve Schmukler, 2007). Olması gereken ilk önce ülke içerisinde yasal alt yapıyı oluşturmak ve yerli gerekli mali kurumları belirli olgunluk seviyelerine ulaştırmak daha sonra finansal gelişme ve serbestleşme amacına yönelik olarak sermaye hareketliğine artırmaktır.

“Kurumsal yapıların, gelişmelerin, finansal gelişmişlik göstergeleri üzerinde nasıl etkisi vardır?" şeklinde geliştirilen sorulara cevap niteliği taşıyan çalışmalara bakıldığında, yasal düzenleyici kurumların etkilerinin çok olduğu vurgusu yapılmıştır. Özellikle mülkiyet haklarının korunması ile düzenleme yapan kurumlar, ikili ya da çok taraflı yapılan sözleşmelerin takip ve yükümlülüklerini takip eden kurumlar ile muhasebe ve finansal düzenlemeleri doğru bir biçimde uygulanmasını sağlayan kurumların, finansal gelişmişlik üzerinde etkilerinin olduğu ifade edilmektedir. La Porta ve diğ. (1997, 1998), “Finans ve Hukuk Hipotezi”nde İngiliz Hukuku'nu baz alan, ağırlıklı olarak sivil katılımı yüksek olan hukuk tabanlı sistemler şeklinde ifade edilen, ortak hukuk tabanlı sistemler (common law based systems), sermaye piyasalarının gelişimi için daha uygun olduğunu ileri sürmüşlerdir. Özellikle, İngiliz Hukuk Sistemi, özel mülkiyetin korunması ile ilgili düzenlemelerde diğer hukuk düzenlerinden daha ileride olduğu görülmektedir (Baltagi ve diğ. 2007: 2). İngiliz Hukuk Sistemi, yatırımcıların haklarını devlete karşı koruyarak bireylerin güven içinde işlem yapacakları şekilde sistemlerini oluşturmuşlardır. Diğer taraftan Fransız Hukuk Sitemine göre ise, firmaların ve yöneticilerinin çıkarları, bireysel yatırımcıya göre daha üstün tutulmuştur. Bundan dolayı da, İngiliz Hukuk Sistemi'nden beslenen ülkelerde sermaye piyasları, Fransız Hukuk Siteminden beslenen ülkelere göre daha gelişmiştir (Agır, 2010: 126-127). Kurumsal düzenlemelere gidilerek sermayenin serbestleşmesi/gelişmesi için çeşitli ülkelerde yapılan yasal düzenlemeler Tablo 1'de bir arada görülmektedir.

Tablo 1: Çeşitli Ülkelerdeki Finansal Liberalleşme İe ilgili Kurumsal Düzenlemeler

\begin{tabular}{|c|c|c|}
\hline Arjantin & $6 / 1980$ & Arjantin'deki yabancı portföy yatırım kısıtlamalarının hafifletilmesi \\
\hline Brezilya & $6 / 1990$ & $\begin{array}{l}\text { Sermaye giriş sınırlamaları ve sermaye dönüşünde liberalleşmeye } \\
\text { gidilmesi. }\end{array}$ \\
\hline Şili & $1 / 1988$ & Kar payı geri dönüşlerinde serbestleşmeye gidilmesi. \\
\hline Kolombiya & $12 / 1989$ & $\begin{array}{l}\text { Portföy ve doğrudan yabancı yatırım kısıtlamaları hafifletildi; aynı } \\
\text { zamanda 12/1991'de kazançların ülke dışına çıkarılmasındaki } \\
\text { kısıtlamalarda liberalleşmeye gidildi. }\end{array}$ \\
\hline Hindistan & $5 / 1990$ & $\begin{array}{l}\text { Yabancı şirketlerin ve yabancı yatırımcıların } \% 40 \text { oranında } \\
\text { özkaynak yatırımlarına otomatik serbestleşme getirildi; aynı } \\
\text { zamanda } 1992 \text { yılında sermaye kar paylarının ülke dışına } \\
\text { çıkarılmasında liberalleşmeye gidildi. }\end{array}$ \\
\hline Ürdün & $1 / 1987$ & Sermayenin dışarı çıkarılmasında liberalleşmeye gidildi. \\
\hline Güney Kore & $8 / 1981$ & $\begin{array}{l}\text { Doğrudan yabancı sermaye yatırımların giriş ve çıkışları } \\
\text { serbestleştirildi. }\end{array}$ \\
\hline
\end{tabular}




\begin{tabular}{|c|c|c|}
\hline & $2 / 1992$ & Portföy yatııımlarının girişinde ve çıkışında serbestleşmeye gidildi. \\
\hline Malezya & $11 / 1986$ & $\begin{array}{l}\text { Doğrudan yabancı sermaye ve portföy yatırımlarının girişi ile ilgili } \\
\text { kısıtlamalar kaldırıldı. }\end{array}$ \\
\hline Meksika & $5 / 1989$ & Doğrudan yabancı yatırım girişinde serbestleşmeye gidildi. \\
\hline Pakistan & 1990 & Kar payı ve sermaye çıkışlarında liberalleşmeye gidildi. \\
\hline Filipinler & 1988 & $\begin{array}{l}\text { Kar payı ve sermaye çıkışlarında liberalleşmeye gidildi; } 1992 \text { yılında } \\
\text { ise daha da yoğunlaştı. }\end{array}$ \\
\hline Portekiz & 1988 & $\begin{array}{l}\text { Kar payı çıkışlarında liberalleşmeye gidildi; takip eden süreçte ise } \\
1989 \text { ve } 1990 \text { yıllarında doğrudan yabancı yatırımları hususunda } \\
\text { tam serbestleşmeye gidildi. }\end{array}$ \\
\hline Tayvan & $2 / 1991$ & Borsa yabancı sermaye yatırımlarına açık hale getirildi. \\
\hline Tayland & 1988 & Kar payı ve sermaye çıkışlarında liberalleşmeye gidildi. \\
\hline Türkiye & 1989 & $\begin{array}{l}\text { Türk Parası Kıymetini Koruma Hakkında } 32 \text { Sayılı Karar"ın } \\
\text { yürürlüğe konulması; yabancı sermayenin istediği kadar para ile } \\
\text { piyasaya girebilmesi ve istediği kadar parayı yurt dışına çıkarması }\end{array}$ \\
\hline Venezuella & $1 / 1990$ & $\begin{array}{l}\text { Doğrudan yabancı sermaye ve portföy yatırımlarının girişi ile ilgili } \\
\text { kısıtlamalar kaldırıldı. }\end{array}$ \\
\hline
\end{tabular}

Kaynak: Levine ve Zarvos, 1998

\subsection{Politik Düzenlemeler}

Hükümetlerin finansal serbestleşmelerle (deregülasyonlar) yabancı sermayeyi kendi ülkelerine çekme çabaları yeni yasal düzenlemelere gidilmesini de zorunlu hale getirmiştir. Türkiye'de 24 Ocak 1980 kararları ve 1989 yılında Türk Lira'sının değerinin korunması ile ilgili çıkarılan kanunların temelinde yabancı sermayenin ülkeye gelişini hızlandırmak olduğu görülmektedir. Benzer düzenlemelerin yalnızca gelişmekte olan ekonomilerde yapılmadığını aynı zamanda gelişmiş ülke ekonomilerinde de yapıldığı görülmektedir.

Bilimsel literatürde, finansal serbestleşme ile ilgili düzenlemelerin piyasaları takip etmesi değil de, ülkeler tarafından üretilen politikaların finansal gelişmeyi teşvik edecek biçimde oluşturulması daha doğru yöntem olduğu söylenebilir. Genellikle, gelişmekte olan ülkelerin finansal gelişmesine bakıldığı zaman, politik düzenlemelerin daha önceden yapıldığı görülmektedir.

\subsection{Hukuksal Düzenlemeler}

Hukuki düzenlemeler hem firmaların haklarını, hem de yatırımcıların haklarını güvence altına alan bir sistemdir. Finansal piyasaların gelişimi açısından, yasal düzenlemelerinin yeri çok önemlidir. Eğer hukuki düzenlemeler sürecin getirdiği değişimi ve yeniliği içine alacak şekilde kendini yenilerse, piyasaların gelişimine olan katkılarının artacağı kesindir. Tersi durumda, hukuk sistemi kurallarını oluşturup, daha sonra piyasaların buna uyması yönünde bir yaklaşım içerisinde olunursa, piyasaların gelişimi daha yavaş olacağı söylenebilir.

Hukuki düzenlemeler ve finansal piyasalar açısından genel kabul gören düşünce, değişen koşullara, hukukun uyum sağlaması gerektiği yönündedir. Hukuki düzenlemeler açısından esnek yapıya sahip olan ülkeler, finansal piyasaların değişiminde ve gelişiminde daha avantajlıdırlar. İngiltere Hukuk Sistemi örnek olay temelli bir biçimde hareket ettiği için zaman içinde oluşan ihtiyaçlara hukuki sistem hızlı bir biçimde cevap vermektedir. Oysa, Fransız Hukuk Sisteminde ise değiştirilemez yasal düzenlemelerin çok olmasından dolayı, yani reformların yapılmasında karşılaşılan zorluklardan dolayı finansal piyasaların gelişimi de yavaşlamaktadır (Ağır, 2010:127).

Hukuksal düzenlemeler ile finansal gelişme arasında yapılan çalışmalara bakıldığında farklı görüşlerin ileri sürüldüğü görülmektedir. Hukuki düzenlemelerde, daha çok yatırımcıların korunması yönünde ağırlık oluştuğu görülmektedir. Nijerya, Pakistan ve Zimbavye gibi ülkelerin daha esnek yapılı olan İngiliz Hukuki Sistemlerini uygulamalarına rağmen finansal piyasaların gelişimine çare olamamıştır. Diğer taraftan, değişime daha kapalı olan Fransız Hukuk Sistemini ağırlıklı olarak uygulayan Hollanda, Lüksemburg ve Belçika gibi ülkelerin finansal piyasalarının geliştiği görülmüştür (Girma ve Shortland, 2004: 4). 


\subsection{Coğrafi Özellikler}

Ülkelerin ilk kuruluş yerlerinin ve coğrafi özelliklerin finansal piyasaların oluşum ve gelişiminde etkilerinin olduğuna dair bazı çalışmalar yapılmıştır. Acemoğlu ve diğ. $(2001,2002)$ coğrafi faktörlerin, finansal gelişmenin önemli bir belirleyici olduğunu ileri sürmüşlerdir. Ülkelerin coğrafi yapılarındaki ulaşım kolaylığı ve sınır ülkelerinin gelişmiş olmasının sermaye hareketliliğini kendi ülkesine doğru çekmesine olumlu etki edebilecektir. Easterly ve Levine (1997), bazı bölgesel etnik yapılanmaların da finansal gelişim süreci üzerine etkilerinin olabileceğinden bahsetmişledir (Naceur ve diğ. 2014).

\subsection{Finansal Sektör Gelişimine Etki Eden Diğer Faktörler}

Finansal sektör gelişimine etki eden, fakat geçmiş çalışmalarda güçlü ilişkiler saptanamayan etkenlerden biri de dini inançlardır. Bazı dini inançlar yerel şartlarda, finansal gelişmeyi kısıtlayıcı yönde etkili olabileceğine dair görüşler vardır. Bazı çalışmalarda, dini inançların finansal gelişmeye olan etkileri de araştırılmış fakat çok güçlü etkinin varlığına dair sonuçlara ulaşılamamıştır (Beck ve diğ. 2004).

Boyd ve diğ (2001), enflasyon ve finansal gelişme arasındaki ilişkiyi araştırmışlar. Enflasyonun finansal gelişme üzerinde negatif etkisinin olduğu ifade edilmiştir. Enflasyonun var olduğu ve yüksek faiz oranlarının uygulanmadığı ülkelerde ulusal para cinsinden yapılan tasarrufların erimesine neden olmaktadır. Firmalar reel ya da finansal tasarruflarını enflasyon riskine karşı korumak için alternatif finansman araçlarına yatırarak daha doğru süreçler oluşturabilmektedirler. Yani tasarruflarını faizin dışındaki enstrümanlara yönlendirmektedirler. Böyle olunca da finansal piyasaların gelişmesine katkı sağlamaktadırlar (Naceur ve diğ. 2014).

Ülke dışına çalışmaya gidenlerin, tasarruflarını kendi ülkelerinde değerlendirmek istemeleri de finansal piyasaların gelişmesine katkı sağlamaktadır. Aggarwal ve diğ. (2006), doğrudan sermaye yatırımlarından sonra, en fazla fon akışını sağlayan kalemin yurt dışı çalışanların kendi ülkelerine aktardıkları fonların olduğunu belirtmişler. Yurt dışı çalışanların göndermiş oldukları tasarrufların, yerel olarak faaliyetlerini yürüten bankaların, banka mevduatlarının artmasına ve kredi kullandırma imkanlarının gelişmesine sebep olduklarını ifade etmektedirler. Orozco ve Fedewa (2005), çalışanların sağladığı döviz transferlerinin finansal gelişmeyi sağlayabileceğini belirtmektedirler. Özellikle finansal kurumlar aracılığıyla yapılan para transferlerinin finansal ürünlerin ve servislerin gelişmesine katkı sağladığı ifade edilmektedir.

Etnik yapının farklı olması ve diğer ülke etnik yapıları ile oluşturulan güçlü bağlar sonrası sağlanan reel ve finansal kaynakların da finansal piyasaların gelişmesine katkı sağlayacağı belirtilmektedir. Ülkelerin geçmişten gelen güçlü ilişkileri, sınır ülkeler arası oluşturulan güçlü ilişkiler ve geçmişten gelen etnik bağlantılarının finansal sektör piyasalarının gelişmesine katkı sağladığı ileri sürülmektedir (Beck ve diğ. 2004).

\section{FINANSAL GELIŞMişLiĞiN PIYASALAR AÇISINDAN ÖNEMi}

Son yıllarda üzerinde en çok durulan konuların başında finansal gelişme/serbestleşme ve sermaye kontrollerinin geldiği görülmektedir. Hem finansal gelişmelerin hem de finansal kısıtlamaların büyüme, yatırımlar, finansal piyasalar ve kurumların üzerinde nasıl bir etkiye sahip olduğunun tespiti için ampirik çalışmaların yapıldığı görülmektedir. Bir çok ülkede, finansal serbestleşme ve gelişme süreçleri yaşanmasına karşın, neden oldukları sonuçlar konusunda farklılıkların olduğu yazılmaktadır.

Genel olarak finansal gelişmenin/liberalleşmenin piyasalar üzerinde pozitif yönlü etkisinin ve öneminin çok fazla olduğu yazılmasına karşın, finansal gelişmenin/serbestleşmenin piyasaları aşırı genişlettiği ve varlık fiyatlarının gereksiz artışına neden olduğu görüşü de dikkatten kaçmamalıdır (Kaminsky ve Schmukler (2007).

\section{LITERATÜR TARAMASI}

Levine ve Zarvos (1998), makalelerinde, 16 gelişmekte olan ülkede iki soruya cevap aramışlardır. Bunlardan birincisi, borsanın büyümesine, likiditesinin artmasına, dalgalanmasına ve sermayenin serbestleşmesine neyin neden olduğu, ikincisi ise, borsa büyüklüğü, likidite, volatilite ve uluslararası bütünleşme ve bilginin açığa çıkarılmasına ilişkin düzenlemelerin, muhasebe standartlarının ve yatırımcıların korunması arasındaki ampirik ilişkilerin neler olduğuna cevap aramışlardır. Borsaların serbestleşme sonrasında daha büyük, daha likit, daha 
volatil ve daha entegre olma eğiliminde olduğunu ileri sürmüşler. Finansal gelişme ile birlikte bilginin yayılması, likiditenin artması ve piyasalar arasında entegrasyonun daha fazla arttığını belirtmektedirler.

Calderon ve Lui (2002), 1960-1994 yıllarını kapsayan 109 gelişmiş ve gelişmekte olan ülkeyi çalışmalarına dahil etmişler. Finansal geliş̧me ile ekonomik büyüme arasındaki ilişkiyi araştırmışlar. Elde ettikleri sonuçları maddeler halinde sıralamışlar. (1) Genellikle finansal gelişmenin ekonomik büyümeye yol açıı̆ı, (2) granger nedenselliğinin hem ekonomik büyümeden finansal gelişmeye doğru, hem de finansal gelişmeden ekonomik büyümeye doğru olduğunu, (3) finansal derinleşmenin gelişmekte olan ülkelerde, gelişmiş ülkelere göre daha fazla etkiye sahip olduğunu, (4) belirlenen yıllar arasında finansal gelişmenin ekonomik büyüme üzerindeki etki süresinin daha uzun olduğunu, (5) finansal derinleşmenin daha hızlı sermaye birikimine ve verimlilik artışına neden olduğunu ileri sürmüşlerdir.

Raddatz (2006), 1981-1998 (1980-1989) dönemlerini kapsayan 48 ülkeye ait 70 imalat sanayi şirketinin finansal gelişmişlikleri ile makro ekonomik dalgalanma arasındaki nedensellik ilişkisini araştırmışlar. Çalışmada uygulanan yatay kesit analizi, finansal gelişmenin makro ekonomik dalgalanmayı azaltma yönünde önemli bir nedensellik ilişkisi ortaya çıkardığını göstermiştir. Illaveten, finansal gelişmenin, likidite ihtiyacı yüksek olan sektörlerin dalgalanmaların azalmasına neden olduğu da ifade edilmiştir.

Kaminsky ve Schmukler (2007), yazmış oldukları makalelerinde finansal serbestleşmenin kronolojisi ve finansal serbestleşmenin etkilerini araştırmışlar. Finansal liberalleşmenin kısa sürede piyasalarda balonlar ve başarısızlıkların oluşmasını tetiklediğini, uzun dönemde ise finansal piyasaların ve kurumların istikrarlı çalışmasına vesile olduklarını ileri sürmüşlerdir.

Acaravcı ve diğ. (2007), 1986:Q1-2006:Q4 yıllarını kapsayan çeyrek dönemlik verilerle Türkiye'deki finansal gelişmişlik ile ekonomik büyüme arasındaki ilişkiyi nedensellik ilişkisi kapsamında incelemişler. Johansen eşbütünleşme analizi ile finansal gelişme ile ekonomik büyüme arasında uzun dönemde herhangi bir ilişki bulunmadığııı ileri sürmüşler. Aynı çalışmada VAR yöntemi ile finansal gelişmişlik ile ekonomik büyüme arasında nedenselliği incelemişler. Finansal gelişmeden ekonomik büyümeye doğru bir nedenselliğin olduğunu belirtmişler.

Cherif and Kaouther (2008), MENA (Middle East and North Africa- Ortadoğu ve Kuzey Afrika) ülkelerinde borsaların makro ekonomik ve kurumsal belirleyicileri üzerine yapmıs oldukları çalışmalarında, borsaların en önemli belirleyicilerinin gelir düzeyi, tasarruf oranları, borsaların likidite düzeyleri ve faiz oranlarının olduğunu belirtmektedirler. Finansal aracılık faaliyetlerinin gelişmesinin borsaların gelişmesinde önemli bir tamamlayıcı unsurun olduğunu ifade etmişlerdir. Kurumsal çevrenin borsalar üzerinde herhangi bir etkiye sahip olmadığını ileri sürmüşlerdir.

Ayaydın ve diğ. (2013), yapmış oldukları çalışmalarında, hisse senedi piyasasının gelişmesinin makro ekonomik ve kurumsal belirleyicilerini 39 gelişmekte olan ülkeye ait 2000-2011 yıllarına ait verileri kullanarak panel veri analizi ile test etmişlerdir. Hisse senedi piyasasının gelişimini temsilen sermaye piyasası kapitilizasyonu bağımlı değişken; reel GSYH, tasarruflar, enflasyon oranı, bankaların vermiş olduğu özel sektör kredileri ve doğrudan yabancı sermaye yatırımları da makro ekonomik değişkenler olarak değerlendirmişler. Kurumsal yapıyı temsil etmek üzere ise, yönetişim endeksi ve politik özgürlükler endeksi olmak üzere iki farklı değişken kullanılmışlar. GSYH, bankaların özel sektör kredileri ve doğrudan yabancı yatırımlar ile hisse senedi piyasalarının gelişmesi arasında doğru yönlü bir ilişkinin olduğunu, ancak tasarruflar ile sermaye piyasasının gelişimi arasında herhangi bir ilişkinin olmadı̆̆ını ileri sürmüşlerdir. Yönetişimin kalitesi ile hisse senedi piyasalarının gelişmesi arasında ise doğru yönlü bir ilişki olduğu, politik özgürlükler ile hisse senedi piyasalarının gelişmesi arasında bir ilişki olmadığını ileri sürmüşlerdir.

Akıncı ve diğ. (2014), Türkiye'de 1986-2012 dönemi yıllık verilerini kullanılarak finansal gelişme ve belirleyicileri arasındaki ilişkiyi VAR analizini kullanılarak araştırmışlar. Araştırma yılları içerisinde finansal piyasaları etkileyen en önemli faktörlerin ulusal hasıla, portföy yatırımları, tasarruf oranları, reel faizler, enflasyon oranı ve cari açık olduğunu belirtmişlerdir. Türkiye'de uzun yıllar boyunca uygulanan yüksek faiz-düşük kur politikasının finansal piyasaların gelişimine katkıda bulunduğunu, ancak bu sürecin de ekonomik kırılganlığı artırdığını ifade etmişlerdir. 


\section{VERILER VE YÖNTEM}

Panel veri; bireyler, ülkeler, firmalar, hane halkları gibi birimlere ait yatay kesit gözlemlerinin belirli bir dönemde bir araya getirilmesiyle oluşan yapıdır (Yerdelen Tatoğlu, 2013: 2). Panel veri N sayıda yatay kesit ve her kesite karşılık gelen T sayıda zaman diliminden oluşur. Panel veri modeli aşağıda gösterilmiştir:

$$
Y_{i t}=\alpha_{i t}+\beta_{\text {kit }}+X_{\text {kit }}+\mu_{\text {it }} \quad i=1, \ldots ., N ; t=1, \ldots . ., T
$$

Panel veri yönteminin avantajlarını su şekilde sıralamak mümkündür (Kaya, 2014: 293):

- Panel veri, kişiler, firmalar, hane halkları ve ülkeler gibi birimlerle zaman içinde ilişki kurduğundan dolayı bu birimler arasında heterojenlik söz konusudur.

- Panel veri, yatay kesit gözlemlerini zaman serisiyle birleştirerek daha bilgilendirici veriler, daha fazla değişkenler, değişkenler arasında daha az doğrusallık ve daha etkin model ortaya koymaktadır.

- Panel veri, sadece yatay kesit ya da sadece zaman serisinde gözlenemeyen etkileri daha iyi teşhis ederek ölçmektedir.

- Panel veri, daha karmaşık davranışlara sahip modeller üzerinde çalışma imkanı sağlamaktadır.

Panel veri gözlem değerlerinin homojen olduğu yani birim ve/veya zaman etkilerinin olmadığı durumlarda klasik modelin; birim ve/veya zaman etkilerinin bulunduğu hallerde ise sabit veya tesadüfi etkiler modellerinin kullanılmasının daha doğru olduğu söylenebilir (Yerdelen Tatoğlu, 2013: 164).

Panel veri ekonometrisinde yatay kesit ve zaman etkileri, sabit etki veya tesadüfi etki modelleriyle açıklanmaktadır. Sabit etkiler modeli, birim etkilerin ( $\mu$ i) dolayısıyla birimler arası farklılıkların sabit olduğu ve sabit terimdeki farklılıklarla ifade edilebildiği durumlarda kullanılmaktadır (Yerdelen Tatoğlu, 2013: 103). Sabit etkiler modelinde, sabit katsayılar kesit veriler arasında veya zaman veriler arasında ya da her iki veri içinde farklılık göstermektedir. Buna karşın modeldeki eğim katsayıları sabittir (Alptekin, 2012: 207).

Sabit etkiler modeli (2) numaralı denklem ile gösterilebilmektedir (Kaya, 2014: 296).

$$
Y_{i t}=\beta+\alpha_{i}+\beta_{1} X_{1 i t}+\ldots+\beta_{k} X_{k i t}+\mu_{i t} \quad i=1, \ldots . ., N ; t=1, \ldots . ., T
$$

Tesadüfi etkiler modelinde her bir kesit birimi için farklı trend değerlerinin söz konusu olduğu, bu trend değerlerinin zaman süresince sabit kaldığı ve bağımlı ve bağımsız değişkenler arasında geçici bir yatay kesit ilişkisinin varlığı öne sürülmektedir (Kaya, 2014: 297). Tesadüfi etkiler modelini ise aşağıdaki şekilde göstermek mümkündür (Wooldridge, 2013: 492).

$$
Y_{i t}=\beta_{0}+\beta_{1} X 1_{i t}+\ldots+\beta_{k} X k_{i t}+\alpha_{i}+\mu_{i t} \quad i=1, \ldots . ., N ; t=1, \ldots . ., T
$$

Çalışmada 2000-2012 dönemine ait yıllık veriler kullanılmıştır. Verilerin elde edilmesiyle ilgili sorunlar çalışma döneminin günümüze ulaşmasını engellemiştir. Çalışmada verilerinden yararlanılan ülkeler, Birleşmiş Milletler Ticaret ve Kalkınma Konferansının (UNCTAD) gelişmiş ve gelişmekte olan ekonomiler listesinden oluşturulmuştur. Altı gelişmiş ve aynı sayıda gelişmekte olan ekonomi çalışmaya dahil edilmiştir (Tablo 2).

Tablo 2: Örneklem Ülkeleri

\begin{tabular}{|l|l|}
\hline GELIŞMiş EKONOMiLER & GELiŞMEKTE OLAN EKONOMiLER \\
\hline Kanada, Fransa, Almanya, İtalya, Japonya ve ABD & $\begin{array}{l}\text { Brezilya, Çin, Hindistan, Malezya, Rusya Federasyonu } \\
\text { ve Türkiye }\end{array}$ \\
\hline
\end{tabular}

Çalışmada kullanılan veriler Dünya Bankası (WB), econstat.com, Ekonomik İşbirliği ve Kalkınma Örgütü (OECD) ve Birleşmiş Milletler Ticaret ve Kalkınma Konferansından (UNCTAD) elde edilmiştir. Verilerin temininde yaşanan güçlükler örneklemin zamanını ve kesitini (ülke sayısını) etkilemiştir. 
Tablo 3: Çalışmada Kullanılan Bağımlı ve Bağımsız Değişkenler ile Tanımları

\begin{tabular}{|c|c|c|c|}
\hline & Değişkenler & $\begin{array}{l}\text { Değişkenlerin } \\
\text { Kısaltması }\end{array}$ & Değişkenlerin Açıklaması \\
\hline \multirow{3}{*}{ 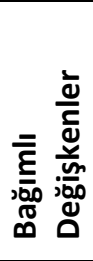 } & Borsa Endeksleri & Y1 & $\begin{array}{l}\text { İlgili Ülkelere ve Yıllara Ait Yılsonu Kapanış Endeks } \\
\text { Değerleri }\end{array}$ \\
\hline & $\begin{array}{l}\text { Piyasa Büyüklüğünün } \\
\text { Büyümeye Oranı }\end{array}$ & Y2 & $\begin{array}{l}\text { Sermaye Piyasası Kapitilizasyonunun Büyümeye } \\
\text { Oranı (\%) }\end{array}$ \\
\hline & $\begin{array}{l}\text { Banka Mevduatlarının } \\
\text { Büyümeye Oranı }\end{array}$ & Y3 & Banka Mevduatlarının Büyümeye Oranı (\%) \\
\hline \multirow{7}{*}{ 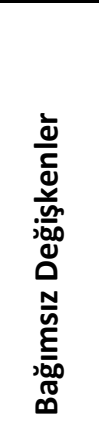 } & Faiz Oranları & $\mathrm{X} 1$ & Faiz Oranları (\%) \\
\hline & Döviz Kuru & $\mathrm{X} 2$ & $\begin{array}{l}\text { ABD Doları/Ulusal Para Şeklindedir. ABD'de ise } \\
\text { Japon Yeni/ABD Doları şeklindedir. }\end{array}$ \\
\hline & $\begin{array}{l}\text { Doğrudan Yabancı } \\
\text { Sermaye Yatırımları }\end{array}$ & X3 & $\begin{array}{l}\text { Doğrudan Yabancı Sermaye Yatırımları (DYSY) Yıllık } \\
\text { Toplam Giriş Tutarı }\end{array}$ \\
\hline & Cari İşlemler Dengesi & $\mathrm{X} 4$ & Yıllık Cari işlemler Dengesi (Açık ya da Fazla) \\
\hline & Büyüme Oranları & $\mathrm{X5}$ & Yıllık Büyüme Oranları (\%) \\
\hline & Enflasyon Oranları & X6 & $\begin{array}{llll}\text { Enflasyon, Tüketici } & \text { Fiyat } & \text { Endeksindeki } & \text { Yıllık } \\
\text { Değişim(\%) } & & & \\
\end{array}$ \\
\hline & $\mathrm{M} 2$ & $\mathrm{X} 7$ & M2 Para Arzı \\
\hline
\end{tabular}

Tablo 4'de tanımlayıcı istatistikler görülmektedir. Finansal piyasalardaki gelişmişliği temsilen borsa endeksleri, sermaye piyasası toplamının büyümeye oranı ve banka mevduatlarının büyümeye oranları kullanılmıştır. Sermaye piyasası büyüklüğünün büyümeye oranı gelişmekte olan ekonomilerde $\% 66,7$, gelişmiş ekonomilerde ise $\% 78,8$ gerçekleşmiştir. Banka mevduatlarının büyümeye oranı ise gelişmekte olan ekonomilerde \%55,1, gelişmiş ekonomilerde ise \%107,7 şeklindedir. Bu değerlere göre gelişmiş ekonomilerdeki finansal piyasaların daha gelişmiş olduğu anlaşılmaktadır. Ancak gelişmekte olan ekonomilerde sermaye piyasalarının piyasaya sundukları kaynak miktarının, bankaların mevduat yoluyla sundukları kaynaklardan daha çok olduğu görülmektedir. Gelişmiş ekonomilerde ise durum tersinedir. Yani banka yoluyla ortaya çıkan kaynak oranı sermaye piyasasının sağladığı kaynaklardan oransal olarak fazladır. Bu durumla ilgili olarak, gelişmekte olan ekonomilerin sermaye piyasalarına gelişmiş ekonomilerden fon akışı olduğu ve gelişmekte olan ekonomilerde tasarruf yetersizliği nedeniyle bankaların yeterince mevduat oluşturamadığı ifade edilebilir.

Faiz oranları gelişmekte olan ülkeler için \%10,11 gelişmiş ekonomiler içinse \%3,55 şeklinde görülmektedir. Bu durum faiz oranlarını meydana getiren risk primlerinin gelişmekte olan ekonomilerde daha fazla olduğunu ortaya koymaktadır.

Tablo 4: Tanımlayıcı İstatistikler, Gelişmekte Olan Ekonomiler

\begin{tabular}{|lcccccc|}
\hline & Ortalama & Ortanca & $\begin{array}{c}\text { Maksimum } \\
\text { Değer }\end{array}$ & $\begin{array}{c}\text { Minimum } \\
\text { Değer }\end{array}$ & $\begin{array}{c}\text { Standart } \\
\text { Sapma }\end{array}$ & $\begin{array}{c}\text { Gözlem } \\
\text { sayısı }\end{array}$ \\
\hline Y1 & 18.906 & 10.818 & 78.579 & 646 & 21527 & 68 \\
\hline Y2 & 66,72 & 55,50 & 148,56 & 16,02 & 39,78 & 68 \\
\hline Y3 & 55,15 & 46,14 & 126,25 & 12,51 & 31,04 & 68 \\
\hline X1 & 10,11 & 8,20 & 51,00 & 1,59 & 8,96 & 68 \\
\hline X2 & 11,97 & 3,80 & 53,43 & 1,30 & 14,62 & 68 \\
\hline X3 & 32.516 & 21.116 & 123.985 & 553 & 31.582 & 68 \\
\hline X4 & 35.007 & 14.532 & 420.569 & -91.471 & 93.541 & 68 \\
\hline X5 & 6,00 & 6,08 & 14,19 & $-7,82$ & 3,78 & 68 \\
\hline X6 & 7,42 & 6,42 & 44,96 & $-0,76$ & 6,99 & 68 \\
\hline X7* & 15.644 & 2.029 & 97.414 & 139 & 24.115 & 68 \\
\hline
\end{tabular}

*Değerler Milyar \$ düzeyindedir. 
Doğrudan yabancı sermaye yatırımları, gelişmekte olan ekonomiler için ortalama 32.5 Milyar \$, gelişmiş ekonomilerde ise 59.7 Milyar \$ şeklinde gerçekleşmiştir. Bu veriler çalışmanın zaman periyodu olan 2000-2012 döneminin ortalamasını vermektedir. Oysa gelişmekte olan ekonomilere yönelen doğrudan yabancı sermaye yatırımlarında önemli artışlar görülmektedir. Hatta gelişmiş ve gelişmekte olan ülke sınıflandırmasında toplam olarak doğrudan yabancı sermaye yatırımlarındaki giriş miktarı neredeyse eşit hale gelmiş durumdadır. UNCTAD verilerine göre 2014 yılında, gelişmiş ekonomilere gelen doğrudan yabancı sermaye yatırımları 498 Milyar \$’ken gelişmekte olan ekonomilere gelen miktar ise 681 Milyar \$ olmuştur.

Cari işlemler dengesine bakıldığında gelişmekte olan ekonomilerde ortalama olarak 35 Milyar \$ fazla, gelişmiş ekonomilerde ise 53 Milyar \$ açık olduğu görülmektedir. Gelişmekte olan ekonomilerde özellikle Çin, Malezya ve Rusya Federasyonunun cari dengesindeki fazlalıklar dikkat çekerken gelişmiş ekonomilerde ise aynı dönemde A.B.D., İngiltere, İtayla ve Fransa'daki cari işlemler açıkları dikkat çekicidir.

Tablo 4: Tanımlayıcı İstatistikler, Gelişmiş Ekonomiler (Devam)

\begin{tabular}{|lcccccc|}
\hline & Ortalama & Ortanca & $\begin{array}{c}\text { Maksimum } \\
\text { Değer }\end{array}$ & $\begin{array}{c}\text { Minumum } \\
\text { Değer }\end{array}$ & $\begin{array}{c}\text { Standart } \\
\text { Sapma }\end{array}$ & $\begin{array}{c}\text { Gözlem } \\
\text { sayısı }\end{array}$ \\
\hline Y1 & 8.449 & 6.605 & 31.892 & 879 & 7.140 & 68 \\
\hline Y2 & 78.86 & 72.87 & 155.41 & 18.57 & 33.03 & 68 \\
\hline Y3 & 107.72 & 85.95 & 227.05 & 49.37 & 52.93 & 68 \\
\hline X1 & 3.55 & 4.02 & 6.03 & 0.84 & 1.35 & 68 \\
\hline X2 & 20.91 & 1.07 & 125.38 & 0.68 & 41.78 & 68 \\
\hline X3 & 59.795 & 33.094 & 314.007 & -10.835 & 72.153 & 68 \\
\hline X4 & -53.300 & 11.168 & 255.383 & -798.469 & 262.982 & 68 \\
\hline X5 & 1.31 & 1.69 & 5.12 & -5.63 & 2.12 & 68 \\
\hline X6 & 1.62 & 1.96 & 3.83 & -1.34 & 1.21 & 68 \\
\hline X7 ${ }^{*}$ & 207.740 & 2.003 & 1.226 .522 & 733 & 423.649 & 68 \\
\hline
\end{tabular}

*Değerler Milyar \$ düzeyindedir.

Büyüme oranları çalışma örneklemi dahilinde, gelişmekte olan ekonomiler için \%6, gelişmiş ekonomiler için ise \%1,62 görülmektedir. UNCTAD verilerine göre, genel olarak örneklem zaman dilimi olan 2000-2012 döneminde büyüme oranları, gelişmekte olan ekonomiler için $\% 5,73$, gelişmiş ekonomiler için $\% 1,63$ ve dünya geneli içinse $\% 2,73$ şeklindedir. Örneklemdeki gelişmekte olan ekonomilerde büyüme oranının küçükde olsa UNCTAD verilerindeki tüm gelişmekte olan ekonomlerden fazla olduğu görülmektedir. Bunun muhtemel sebeplerinden birisi çalışma örneklemindeki Çin'dir. Çünkü, örneklem verilerinde Çin'in büyüme oranı \%10,06'dır. Ayrıca yine örneklem verilerinde 2008-2009 küresel ekonomik ve finans krizinde ekonomik küçülme yaşamayan tek ülke de Çin ekonomisi görülmektedir. Gelişmiş ekonomilerdeki büyüme oranı, tüm gelişmiş ekonomilerin içinde bulunduğu büyüme oranıyla hemen hemen aynıdır.

Gelişmekte olan ekonomilerde ortalama enflasyon oranı \%7,42, gelişmiş ekonomilerde ise \%1,62 şeklindedir. M2 para arzının, gelişmekte olan ekonomilerde 15.644 Milyar \$, gelişmiş ekonomilerde ise 207.740 Milyar \$ olduğu görülmektedir.

Tablo 5: Değişkenler Arasındaki Pearson Korelasyon Katsayıları (Gelişmekte Olan Ekonomiler)

\begin{tabular}{|l|lllllllllll|l|l|}
\hline & Y1 & Y2 & Y3 & X1 & X2 & X3 & X4 & X5 & X6 & X7 \\
\hline Y1 & 1 & $-0,361$ & $-0,262$ & 0,262 & $-0,199$ & $-0,094$ & $-0,451$ & $-0,288$ & 0,083 & $-0,268$ \\
& & $(0,001)$ & $(0,016)$ & $(0,016)$ & $(0,052)$ & $(0,223)$ & $(0,000)$ & $(0,009)$ & $(0,253)$ & $(0,014)$ \\
\cline { 1 - 1 } & & 1 & 0,823 & $-0,569$ & $-0,037$ & $-0,056$ & 0,206 & 0,104 & $-0,479$ & 0,030 \\
& & & $(0,000)$ & $(0,000)$ & $(0,383)$ & $(0,326)$ & $(0,046)$ & $(0,200)$ & $(0,000)$ & $(0,404)$ \\
\cline { 1 - 5 } & & & 1 & $-0,464$ & $-0,277$ & $-0,292$ & $-0,136$ & $-0,145$ & $-0,484$ & $-0,135$ \\
& & & & $(0,000)$ & $(0,011)$ & $(0,008)$ & $(0,134)$ & $(0,119)$ & $(0,000)$ & $(0,137)$
\end{tabular}




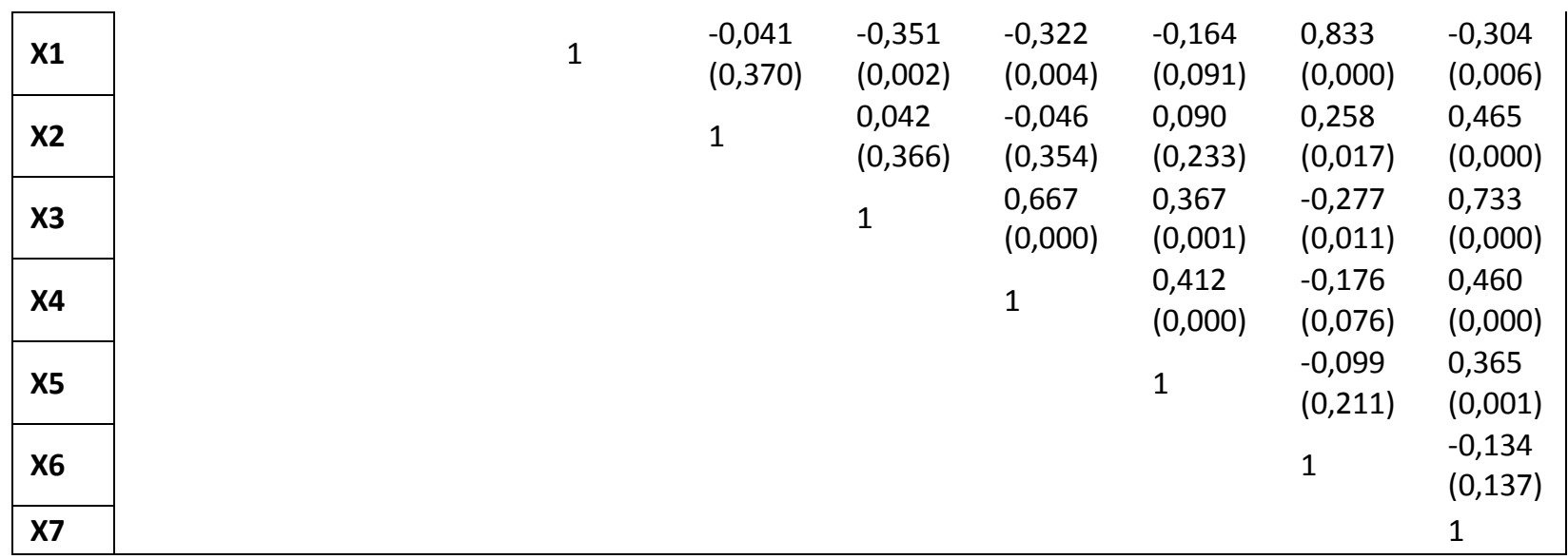

Not: Tablo hücrelerindeki ilk değerler Pearson katsayılarını, parantez içindeki değerler ise anlamlılık düzeylerini göstermektedir.

Tablo 5'de çalışmada kullanılan her iki ülke grupları için değişkenler arasındaki korelasyon katsayıları görülmektedir.

Tablo 5: Bağımsız Değişkenler Arasındaki Pearson Korelasyon Katsayıları (Gelişmiş Ekonomiler - Devam)

\begin{tabular}{|c|c|c|c|c|c|c|c|c|c|c|}
\hline & Y1 & $\mathrm{Y} 2$ & Y3 & $\mathrm{X1}$ & $\times 2$ & X3 & $\mathrm{X4}$ & $\times 5$ & $\mathrm{X6}$ & $\times 7$ \\
\hline Y1 & 1 & $\begin{array}{l}-0,369 \\
(0,001)\end{array}$ & $\begin{array}{l}0,124 \\
(0,156)\end{array}$ & $\begin{array}{l}-0,081 \\
(0,255)\end{array}$ & $\begin{array}{l}0,229 \\
(0,030)\end{array}$ & $\begin{array}{l}-0,461 \\
(0,000)\end{array}$ & $\begin{array}{l}0,403 \\
(0,000)\end{array}$ & $\begin{array}{l}-0,062 \\
(0,307)\end{array}$ & $\begin{array}{l}-0,155 \\
(0,104)\end{array}$ & $\begin{array}{l}0,219 \\
(0,037)\end{array}$ \\
\hline Y2 & & 1 & $\begin{array}{l}-0,010 \\
(0,469)\end{array}$ & $\begin{array}{l}0,217 \\
(0,037)\end{array}$ & $\begin{array}{l}-0,027 \\
(0,413)\end{array}$ & $\begin{array}{l}0,612 \\
(0,000)\end{array}$ & $\begin{array}{l}0,413 \\
(0,000)\end{array}$ & $\begin{array}{l}0,285 \\
(0,009)\end{array}$ & $\begin{array}{l}-0,034 \\
(0,391)\end{array}$ & $\begin{array}{l}-0,369 \\
(0,001)\end{array}$ \\
\hline Y3 & & & 1 & $\begin{array}{l}-, 742 \\
(0,000)\end{array}$ & $\begin{array}{l}0,852 \\
(0,000)\end{array}$ & $\begin{array}{l}-0,413 \\
(0,000)\end{array}$ & $\begin{array}{l}0,490 \\
(0,000)\end{array}$ & $\begin{array}{l}-0,062 \\
(0,308)\end{array}$ & $\begin{array}{l}-0,722 \\
(0,000)\end{array}$ & $\begin{array}{l}0,876 \\
(0,000)\end{array}$ \\
\hline $\mathrm{X1}$ & & & & 1 & $\begin{array}{l}-0,778 \\
(0,000)\end{array}$ & $\begin{array}{l}0,293 \\
(0,003)\end{array}$ & $\begin{array}{l}-0,351 \\
(0,002)\end{array}$ & $\begin{array}{l}0,175 \\
(0,077)\end{array}$ & $\begin{array}{l}0,732 \\
(0,000)\end{array}$ & $\begin{array}{l}-0,796 \\
(0,000)\end{array}$ \\
\hline $\mathrm{X} 2$ & & & & & 1 & $\begin{array}{l}-0,349 \\
(0,002)\end{array}$ & $\begin{array}{l}0,361 \\
(0,001)\end{array}$ & $\begin{array}{l}-0,088 \\
(0,238)\end{array}$ & $\begin{array}{l}-0,756 \\
(0,000)\end{array}$ & $\begin{array}{l}0,980 \\
(0,000)\end{array}$ \\
\hline X3 & & & & & & 1 & $\begin{array}{l}-0,778 \\
(0,000)\end{array}$ & $\begin{array}{l}0,189 \\
(0,062)\end{array}$ & $\begin{array}{l}0,480 \\
(0,000)\end{array}$ & $\begin{array}{l}-0,351 \\
(0,002)\end{array}$ \\
\hline X4 & & & & & & & 1 & $\begin{array}{l}-0,120 \\
(0,165)\end{array}$ & $\begin{array}{l}-0,496 \\
(0,000)\end{array}$ & $\begin{array}{l}0,358 \\
(0,001)\end{array}$ \\
\hline$\times 5$ & & & & & & & & 1 & $\begin{array}{l}0,346 \\
(0,002)\end{array}$ & $\begin{array}{l}-0,094 \\
(0,223)\end{array}$ \\
\hline X6 & & & & & & & & & 1 & $\begin{array}{l}-0,765 \\
(0,000) \\
1\end{array}$ \\
\hline
\end{tabular}

Not: Tablo hücrelerindeki ilk değerler Pearson katsayılarını, parantez içindeki değerler ise anlamlııı düzeylerini göstermektedir.

\section{ANALIZ VE BULGULAR}

Panel veri analizi, hem yatay kesit verisi, hem de zaman serisi özellikleri taşımaktadır. Özellikle panel veri setinde zaman serisinin bulunması verilerin durağan olması bakımından önem taşımaktadır. Yapılan birim kök testlerinde verilerin önemli bir kısmının düzeyde, az bir kısmının 1. farkta ve X7 değişkeninin ise 2. farkta durağan oldukları görülmektedir (Tablo 6). 
Tablo 6: Birim Kök Testi, Gelişmekte Olan Ekonomiler

\begin{tabular}{|c|c|c|c|c|c|c|c|}
\hline \multirow{2}{*}{ Yöntem } & \multirow{2}{*}{ Değiş̧kenler } & \multicolumn{3}{|l|}{ Sabit } & \multicolumn{3}{|c|}{ Sabit ve Trend } \\
\hline & & Düzeyde & 1. Fark & 2.Fark & Düzeyde & 1. Fark & 2.Fark \\
\hline \multirow{12}{*}{$\begin{array}{l}\text { Levin, Lin \& } \\
\text { Chu } \\
\text { (T İstatistiği) }\end{array}$} & Y1 & $(-2,71)^{*}$ & - & - & $(-6,98)^{*}$ & - & - \\
\hline & $\mathrm{Y} 2$ & $(-2,78)^{*}$ & - & - & $(-2,33)^{*}$ & - & - \\
\hline & Y3 & - & $(-5,97)^{*}$ & - & $(-4,23)^{*}$ & - & - \\
\hline & $\mathrm{X} 1$ & $(-4,49)^{*}$ & - & - & $(-4,25)^{*}$ & - & - \\
\hline & $\mathrm{X} 2$ & - & $(-3,73)^{*}$ & - & - & $(-3,65)^{*}$ & - \\
\hline & X3 & - & $(-6,78)^{*}$ & - & $(-6,10)^{*}$ & - & - \\
\hline & LOGX3 & $(-1,99) * *$ & - & - & $(-4,96)^{*}$ & - & - \\
\hline & $\mathrm{X} 4$ & - & $(-5,61)^{*}$ & - & - & $(-25,54)^{*}$ & - \\
\hline & $x 5$ & $(-6,38)^{*}$ & - & - & $(-4,90)^{*}$ & - & - \\
\hline & $\mathrm{x} 6$ & $(-6,86)^{*}$ & - & - & $(-8,30)^{*}$ & - & - \\
\hline & $\times 7$ & - & - & $(-7,81)^{*}$ & - & $(-5,94)^{*}$ & - \\
\hline & LOGX7 & $(-1,73)^{* *}$ & - & - & - & $(-8,00)^{*}$ & - \\
\hline
\end{tabular}

Tablo 6: Birim Kök Testi, Gelişmiş Ekonomiler (Devam)

\begin{tabular}{|c|c|c|c|c|c|c|c|}
\hline \multirow{2}{*}{ Yöntem } & \multirow{2}{*}{ Değişkenler } & \multicolumn{3}{|l|}{ Sabit } & \multicolumn{3}{|c|}{ Sabit ve Trend } \\
\hline & & Düzeyde & 1. Fark & 2.Fark & Düzeyde & 1. Fark & 2. Fark \\
\hline \multirow{11}{*}{$\begin{array}{l}\text { Levin, Lin \& } \\
\text { Chu } \\
\text { (T İstatistiği) }\end{array}$} & $\mathrm{Y} 1$ & $(-3,36)^{*}$ & - & - & $(-2,05)^{* *}$ & - & - \\
\hline & LOGY1 & $(-2,67)^{*}$ & - & - & - & $(-6,26)^{*}$ & - \\
\hline & $\mathrm{Y} 2$ & $(-3,56)^{*}$ & - & - & $(-1,85)^{* *}$ & - & - \\
\hline & Y3 & - & $(-3,24)^{*}$ & - & $(-3,77)^{*}$ & - & - \\
\hline & $\mathrm{X} 1$ & - & $(-4,89)^{*}$ & - & - & $(-3,07)^{*}$ & - \\
\hline & $\mathrm{X} 2$ & $(-4,24)^{*}$ & - & - & - & $(-11,40)^{*}$ & - \\
\hline & X3 & $(-3,68)^{*}$ & - & - & $(-4,49)^{*}$ & - & - \\
\hline & $\mathrm{X} 4$ & - & $(-3,27)^{*}$ & - & - & $(-4,20)^{*}$ & - \\
\hline & $\times 5$ & $(-4,94)^{*}$ & - & - & $(-3,89)^{*}$ & - & - \\
\hline & $x 6$ & $(-6,98)^{*}$ & - & - & $(-6,94)^{*}$ & - & - \\
\hline & LOGX7 & $(-2,54)^{*}$ & - & - & $(-9,95)^{*}$ & - & - \\
\hline
\end{tabular}

Değişkenler arasındaki nedenselliğin testi amacıyla Panel Granger Nedensellik Testi uygulanmaktadır. Nedensellik testinden önce uygun gecikme uzunluğunun tespiti gerekmektedir. Uygun gecikme uzunluğunun testi neticesinde her iki ülke grubunda da Schwartz Bilgi Kriterine göre "1" tespit edilmiştir (Tablo 7).

Tablo 7: Uygun Gecikme Uzunluğu

\begin{tabular}{|c|c|c|}
\hline \multirow{2}{*}{$\begin{array}{c}\text { Gecikme } \\
\text { Uzunlukları }\end{array}$} & \multicolumn{2}{|c|}{ Schwartz Kriterleri (SC) } \\
\cline { 2 - 3 } & Gelişmekte Olan Ekonomiler & Gelişmiş Ekonomiler \\
\hline 0 & 174,58 & $\mathbf{1 7 5 , 8 0}$ \\
\hline 1 & $\mathbf{1 5 8 , 4 7 ^ { * }}$ & $\mathbf{1 5 5 , 7 7 ^ { * }}$ \\
\hline 2 & 161,53 & 159,04 \\
\hline 3 & 162,80 & 158,09 \\
\hline
\end{tabular}

Granger Nedensellik Test sonuçlarına göre, gelişmekte olan ekonomiler grubunda, faiz oranları (X1) ve ekonomik büyümeden (X5) borsa endekslerine (Y) doğru \%10 önem düzeyinde bir nedensellik ile DYSY'dan (X3) piyasa büyüklüğünün ekonomik büyüme oranına (Y2) doğru \%5 önem düzeyinde bir nedensellik vardır.

Tablo 8: Ülke Gruplarına Göre Granger Nedensellik Testi Sonuçları

\begin{tabular}{|l|c|c|c|}
\hline \multicolumn{3}{|l|}{ Gelişmekte Olan Ekonomiler } \\
\hline Değişken Çifti & Nedenselliğin Yönü & F İstatistiği & Olasılık \\
\hline $\mathrm{X} 1-\mathrm{Y} 1$ & $\longrightarrow$ & $3,295^{* * *}$ & 0,074 \\
\hline
\end{tabular}




\begin{tabular}{|c|c|c|c|}
\hline$X 5-Y 1$ & $\longrightarrow$ & $3,304 * * *$ & 0,074 \\
\hline$X 3-Y 2$ & $\longrightarrow$ & $4,325 * *$ & 0,041 \\
\hline \multicolumn{4}{|c|}{ Gelişmiş Ekonomiler } \\
\hline Değişken Çifti & Nedenselliğin Yönü & F İstatistiği & Olasılık \\
\hline$X 3-Y 1$ & $\longrightarrow$ & $2,900 * * *$ & 0,093 \\
\hline
\end{tabular}

Gelişmik ülke gruplarında ise sadece DYSY'dan (X3) borsa endekslerine (Y1) doğru \%10 önem seviyesinde bir

Tablo 9: Gelişmekte Olan Ekonomilerde Borsa Endekslerini Etkileyen nedensellik görülmüştür.

Faktörlere Yönelik Arellano, Froot ve Rogers Tahmin Yöntemi Regresyonu (Y1)

\begin{tabular}{|l|l|l|l|l|}
\hline \multirow{2}{*}{} & \multicolumn{4}{|l}{ Sabit Etkiler Modeli } \\
\cline { 2 - 5 } & Katsayı & $\begin{array}{l}\text { Dayanıklı St. } \\
\text { Hata }\end{array}$ & T İstatistiği & Olasılık \\
\hline X1 & -979.0966 & 283.0849 & -3.46 & $0.018^{* *}$ \\
\hline X2 & -859.6381 & 763.468 & -1.13 & 0.311 \\
\hline LOGX3 & -5491.783 & 3924.838 & -1.40 & 0.221 \\
\hline X4 & -.044863 & .0297567 & -1.51 & 0.192 \\
\hline X5 & 785.5427 & 413.2927 & 1.90 & 0.116 \\
\hline LOGX7 & 14220.76 & 7351.369 & 1.93 & 0.111 \\
\hline Gözlem Sayısı & 68 & & & \\
\hline Grup SayıSı & 6 & & & \\
\hline Zaman Periyodu & 13 & & & 0.0000 \\
\hline $\begin{array}{l}\text { Hausman Testi } \\
\text { (Ki Kare) }\end{array}$ & 556.20 & & & 0.0639 \\
\hline$R^{2}$ (Aralık) & $(0,56-0,60)$ & $\begin{array}{l}\text { Breusch- } \\
\text { Pagan LM }\end{array}$ & 24,073 & \\
\hline Durbin-Watson & 1.4877483 & Wald & 1041.36 & 0.0000 \\
\hline
\end{tabular}

*,** ve *** sırasıyla \%1, \%5 ve \%10 anlam düzeyini ifade eder.

Çalışmada finansal gelişmişliği temsilen üç değişken kullanılmıştır. Bunlar; borsa endeksleri, sermaye piyasaları büyüklüğünün büyümeye oranı ve banka mevduatlarının büyümeye oranı şeklindedir. Bu nedenle üç model oluşturulmuştur.

Model 1A: $Y 1=60+B_{1} X 1+B_{2} X 2+B_{3} L O G X 3+B_{4} X 4+B_{5} X 5+B_{6} L O G X 7+\mu i$

Tablo 3’de görüldüğü gibi yedi bağımsız değişken söz konusudur. Modele alınacak değişkenlerin belirlenmesinde stepwise regresyon yöntemlerinden ileriye yönelik seçim yöntemi (Çakır Zeytinoğlu, 2007: 337) ve değişkenler arasındaki korelasyonlar dikkate alınmıştır.

Klasik model ile panel veri modelleri arasında tercih yapabilmek için olabilirlik oranı (LR) testi kullanılmaktadır. LR testinde birim ve zaman etkisi görüldüğünden klasik modelin uygunluğu red edilmiştir. Panel veri analizinde sabit ve tesadüfi etki modelleri bulunmaktadır. Bu modellerin seçiminde Hausman Testi yapılmaktadır. Bu teste göre sabit etkiler modeli kullanılması gerektiği ortaya çıkmıştır. Modelde varsayımlardan sapmaların tespit edilmesi amacıyla yapılan testlerde değişen varyans ve otokorelasyon sorunuyla karşılaşıldığından model Arellano, Froot ve Rogers dirençli tahmincisiyle gerçekleştirilmiştir. Gelişmekte olan ekonomiler için borsa endekslerini etkileyen makro ekonomik değişkenlerin belirlendiği analiz sonuçları Tablo 9'dadır.

Analiz sonuçlarına göre, faiz oranlarının (X1) \%5 seviyesinde etkisi istatistiksel olarak anlamlı görülmektedir. Buna göre, bu değişken gelişmekte olan ekonomi borsalarında fiyat oluşumunun makro ekonomik belirleyicilerinden birisidir. 
Model 1B: $L O G Y 1=b_{0}+b_{1} X 1+b_{2} X 2+b_{3} X 3+b_{4} X 5+b_{5} X 6+\mu_{i}$

Illeriye yönelik stepwise yöntemi ve değişkenler arası korelasyonlar dikkate alınarak yukarıdaki regresyon oluşturulmuştur. Olabilirlik testinde iki yönlü birim ve zaman etkileri görülmüştür. Hausman testi, sabit etkiler modelinin uygulanması gerektiğini ortaya koymuştur. Varsayımlardan sapmaların belirlenmesi amacıyla yapılan testlerde değişen varyans, otokorelasyon ve birimler arası korelasyon sorunlarıyla karşılaşıldığından Driscoll ve Kraay dirençli tahminci modeli kullanılmıştır.

Tablo 10: Gelişmiş Ekonomilerde Borsa Endekslerini Etkileyen Faktörlere Yönelik Driscoll ve Kraay Dayanıklı Regresyonu (Y1)

\begin{tabular}{|c|c|c|c|c|}
\hline \multirow[b]{2}{*}{ Değişkenler } & \multicolumn{4}{|c|}{ Sabit Etkiler Modeli } \\
\hline & Katsayı & $\begin{array}{l}\text { Drisc/Kraay } \\
\text { St. Hata }\end{array}$ & $\begin{array}{l}\text { T } \\
\text { İstatistiği }\end{array}$ & Olasılık \\
\hline $\mathrm{X} 1$ & -704.6245 & 261.1692 & -2.70 & $0.043^{* *}$ \\
\hline $\mathrm{X} 2$ & 61.74006 & 62.22789 & 0.99 & 0.367 \\
\hline $\mathrm{X3}$ & .0159832 & .0063167 & 2.53 & $0.053^{* * *}$ \\
\hline$\times 5$ & 600.4722 & 231.483 & 2.59 & $0.049 * *$ \\
\hline$x 6$ & -905.1123 & 401.4165 & -2.25 & $0.074 * * *$ \\
\hline Gözlem Sayısı & 68 & & & \\
\hline Grup Sayısı & 6 & & & \\
\hline Zaman Periyodu & 13 & & & \\
\hline $\begin{array}{l}\text { Hausman Testi } \\
\text { (Ki Kare) }\end{array}$ & -8.76 & & & 0,0000 \\
\hline $\mathrm{R}^{2}$ & 0,27 & Pesaran & 2.180 & 0.0293 \\
\hline $\mathrm{F}$ & 6,20 & & & 0.0335 \\
\hline Durbin-Watson & 1.1797067 & Wald & 829.16 & 0.0000 \\
\hline
\end{tabular}

Regresyon sonuçlarına göre, faiz oranları (X1) ve büyüme oranları (X5) \%5, doğrudan yabancı sermaye yatırımları (X3) ve enflasyon oranları (X6) \%10 seviyesinde etkileri anlamlı olan değişkenlerdir.

Bu sonuçlara göre her iki ülke kategorisine göre faiz oranları (X1) borsa endekslerini etkileyen ortak makro ekonomik değişkenlerdir. Gelişmiş ekonomilerde ayrıca doğrudan yabancı sermaye yatırımları (X3), büyüme oranları (X5) ve enflasyon oranı (X6) borsa endeklerini etkileyen faktörler şeklinde görülmüştür.

Model 2A: $Y 2=B_{0}+B_{1} X 1+B_{2} X 2+B_{3} X 3+B_{4} X 4+B_{5} X 5+\mu_{i}$

Modele alınacak değişkenler stepwise yöntemi ve değişkenler arası korelasyonlar dikkate alınarak belirlenmiş, olabilirlik testinde (LR) birim ve zaman etkileri görülmüş ve Hausman testiyle sabit etkiler modelinin seçilmesi gerektiği ortaya çıkmıştır. Değişen varyans, otokorelasyon ve yatay kesit sorunlarına karşı Driscoll ve Kraay dayanıklı regresyon tahmincisi kullanılmıştır. Bu çerçevede yapılan regresyon sonuçları Tablo 11'dedir.

Tablo 11: Gelişmekte Olan Ekonomilerde Piyasa Büyüklüğünün Büyümeye Oranını Etkileyen Faktörlere Yönelik Driscoll ve Kraay Dayanıklı Regresyonu (Y2)

\begin{tabular}{|l|l|l|l|l|}
\hline \multirow{2}{*}{ Değişkenler } & \multicolumn{4}{|l|}{ Sabit Etkiler Modeli } \\
\cline { 2 - 5 } & Katsayı & $\begin{array}{l}\text { Drisc/Kraay } \\
\text { St. Hata }\end{array}$ & T İstatistiği & Olasılık \\
\hline X1 & -.6384788 & .1908173 & -3.35 & $0.020^{* *}$ \\
\hline X2 & -3.590366 & 1.30962 & -2.74 & $0.041^{* *}$ \\
\hline X3 & -.0001049 & .0001325 & -0.79 & 0.464 \\
\hline X4 & .0001639 & .0000334 & 4.91 & $0.004^{*}$ \\
\hline X5 & 1.467738 & .430382 & 3.41 & $0.019^{* *}$ \\
\hline Gözlem Sayısı & 68 & & & \\
\hline Grup Sayısı & 6 & & & \\
\hline
\end{tabular}




\begin{tabular}{|l|l|l|l|l|}
\hline $\begin{array}{l}\text { Zaman } \\
\text { Periyodu }\end{array}$ & 13 & & & \\
\hline $\begin{array}{l}\text { Hausman Testi } \\
\text { (Ki Kare) }\end{array}$ & -42.68 & & & 0.0000 \\
\hline $\mathrm{R}^{2}$ & 0,66 & Pesaran & 1.603 & 0.1090 \\
\hline F İstatistiği & 37.98 & & & 0.0005 \\
\hline Durbin-Watson & 1.5588147 & Wald & 61.15 & 0.0000 \\
\hline
\end{tabular}

*,** ve ${ }^{* * *}$ sırasıyla $\% 1, \% 5$ ve $\% 10$ anlam düzeyini ifade eder.

Tablo 11'de görüldüğü üzere, gelişmekte olan ekonomilerde faiz oranları (X1), döviz kuru (X2), cari denge (X4) ve büyüme oranları (X5) sermaye piyasası büyüklüğü/büyüme oranını etkileyen makro ekonomik değişkenler şeklinde karşımıza çıkmaktadır.

Model 2B: $Y 2=\beta_{0}+\beta_{1} \times 1+\beta_{2} \times 2+\beta_{3} \times 3+\beta_{4} \times 5+\beta_{5} \times 6+\mu_{i}$

Modeldeki değişkenlerin seçilme aşaması stepwise yöntemi ve değişkenler arası korelasyonlar dikkate alınarak gerçekleştirilmiştir. Olabilirlik testiyle (LR) klasik mdeol reddedilmiştir. Hausman testi sabit etkiler modelini ortaya koymuş, değişen varyans, otokorelasyon ve yatay kesit bağımlılı̆̆ sorunlarına istinaden Driscoll ve Kraay dirençli tahminci modeli kullanılmıştır (Tablo 12).

Tablo 12: Gelişmiş Ekonomilerde Piyasa Büyüklüğünün Büyümeye Oranını Etkileyen Faktörlere Yönelik Driscoll ve Kraay Regresyonu

(Y2)

\begin{tabular}{|l|l|l|l|l|}
\hline \multirow{2}{*}{ Değişkenler } & \multicolumn{4}{|l|}{ Sabit Etkiler Modeli } \\
\cline { 2 - 5 } & Katsayı & $\begin{array}{l}\text { Drisc/Kraay } \\
\text { St. Hata }\end{array}$ & $\begin{array}{l}\text { T } \\
\text { i̇statistiği }\end{array}$ & Olasılık \\
\hline X1 & 6.637795 & .9657529 & 6.87 & $0.001^{*}$ \\
\hline X2 & .1235765 & .3294805 & 0.38 & 0.723 \\
\hline X3 & .0000973 & .0000259 & 3.76 & $0.013^{* *}$ \\
\hline X5 & 1.79567 & .6320876 & 2.84 & $0.036^{* *}$ \\
\hline X6 & 1.897135 & 1.269545 & 1.49 & 0.195 \\
\hline Gözlem Sayısı & 68 & & & \\
\hline Grup Sayısı & 6 & & & \\
\hline $\begin{array}{l}\text { Zaman } \\
\text { Periyodu }\end{array}$ & 13 & & & \\
\hline $\begin{array}{l}\text { Hausman Testi } \\
\text { (Ki Kare) }\end{array}$ & -5.50 & & & 0.0000 \\
\hline$R^{2}$ & 0,40 & Pesaran & 2.953 & 0.0031 \\
\hline F İstatistiği & 162.21 & & & 0.000000 \\
\hline Durbin-Watson & .45894708 & Wald & 209.89 & 0.0000 \\
\hline
\end{tabular}

$*, * *$ ve ${ }^{* * *}$ sırasıyla $\% 1, \% 5$ ve $\% 10$ anlam düzeyini ifade eder.

Gelişmiş ekonomilerde ise sermaye piyasası büyüklüğü/büyüme oranını etkileyen faktörler faiz oranı (X1), doğrudan yabancı sermaye yatıımları (X3) ve büyüme oranları (X5) olmuştur. Bu çerçevede finansal gelişmişliği temsilen kullandığımız üç değişkenden birisi olan finansal piyasa büyüklüğü/büyüme oranını etkileyen faktörlerden faiz oranı (X1) ve büyüme oranları (X5) iki ülke grubunda da etkiye sahipken, doğrudan yabancı sermaye yatıımları (X3) sadece gelişmiş ekonomilerde etkiye sahip, döviz kurları (X2) ve cari denge (X4) sadece gelişmekte olan ekonomilerde piyasa büyüklüğü/büyüme oranını etkilemiş̧ir.

Model 3A: $Y 3=B_{0}+B_{1} X 1+B_{2} X 2+63 \operatorname{LOGX3}+B_{4} X 4+B_{5} X 5+66 \operatorname{LOGX7}+\mu_{i}$

Banka mevduatları/büyüme oranını etkileyen makro ekonomik değişkenler her bir adımda en yüksek etkiye sahip değişkenlerin tespitiyle oluşturulmuştur. Olabilirlik testiyle klasik model reddedilmiştir. Hausman testi, sabit etkiler modelinin kullanılması gerektiğini ortaya koymuştur. Karşılaşılan değişen varyans ve otokorelasyon 
sorunları neticesinde dirençli tahminciler yöntemlerinden Arellano, Froot ve Rogers tahmincisine göre regresyon oluşturulmuştur (Tablo 13).

Tablo 13: Gelişmekte Olan Ekonomilerde Banka Mevduatlarının Büyümeye Oranını Etkileyen Faktörlere Yönelik Arellano, Froot ve Rogers Regresyonu (Y3)

\begin{tabular}{|l|l|l|l|l|}
\hline \multirow{2}{*}{ Değişkenler } & \multicolumn{4}{|l|}{ Sabit Etkiler Modeli } \\
\cline { 2 - 5 } & Katsayı & $\begin{array}{l}\text { Dayanıklı } \\
\text { St. Hata }\end{array}$ & $\begin{array}{l}\text { T } \\
\text { İstatistiği }\end{array}$ & Olasılık \\
\hline X1 & -.0930087 & .0934296 & -1.00 & 0.365 \\
\hline X2 & -.1903016 & .2220602 & -0.86 & 0.431 \\
\hline LOGX3 & -2.726349 & .9852727 & -2.77 & $0.040^{* *}$ \\
\hline X4 & -.0000166 & $6.84 \mathrm{e}-06$ & -2.43 & $0.060^{* * *}$ \\
\hline X5 & -.2701982 & .0717021 & -3.77 & $0.013^{* *}$ \\
\hline LOGX7 & 10.24518 & 1.640489 & 6.25 & $0.002^{*}$ \\
\hline Gözlem Sayısı & 68 & & & \\
\hline Grup SayıSı & 6 & & & \\
\hline $\begin{array}{l}\text { Zaman } \\
\text { Periyodu }\end{array}$ & 13 & & & \\
\hline $\begin{array}{l}\text { Hausman Testi } \\
\text { (Ki Kare) }\end{array}$ & -77.37 & & & 0.0000 \\
\hline R ${ }^{2}$ (Aralık) & $(0,03-0,71)$ & Pesaran & -1.434 & 1.8486 \\
\hline $\begin{array}{l}\text { Durbin- } \\
\text { Watson }\end{array}$ & .7258506 & Wald & 159.07 & 0.0000 \\
\hline
\end{tabular}

*** ve *** sırasıyla \%1, \%5 ve \%10 anlam düzeyini ifade eder.

Regresyon sonuçları doğrudan yabancı sermaye yatırımları (LOGX3), cari işlemler dengesi (X4), büyüme oranları (X5) ve M2 para arzının (LOGX7) banka mevduatları/büyüme oranı üzerinde anlamlı etkiye sahip olduğunu göstermektedir.

Model 3B: $Y 3=b_{0}+b_{1} X 2+b_{2} X 4+b_{3} X 5+b_{4} X 6+65$ LOGX7+ $\mu_{i}$

Banka mevduatları/büyüme oranı üzerine etkisi olan makro ekonomik değişkenleri tespit etmek için yüksek etkiye sahip değişkenlerden yukarıdaki model oluşturulmuştur. Olabilirlik testinde (LR) klasik regresyon modeli reddedilmiştir. Hausman testine göre sabit etki ortaya çıkmış, değişen varyans ve otokorelesyon sorunlarına karşı Arellano, Froot ve Rogers dirençli regresyon tahmincisi kullanılmıştır (Tablo 14).

Tablo 14: Gelişmiş Ekonomilerde Banka Mevduatlarının Büyümeye Oranını Etkileyen Faktörlere Yönelik Arellano, Froot ve Rogers Regresyon (Y3)

\begin{tabular}{|l|l|l|l|l|}
\hline \multirow{2}{*}{ Değişkenler } & \multicolumn{4}{|l|}{ Sabit Etkiler Modeli } \\
\cline { 2 - 5 } & Katsayı & $\begin{array}{l}\text { Dayanklı } \\
\text { St. Hata }\end{array}$ & T İstatistiği & Olasılık \\
\hline X1 & -7.581883 & 1.686464 & -4.50 & $0.006^{*}$ \\
\hline X2 & -.4972307 & .0286313 & -17.37 & $0.000^{*}$ \\
\hline X3 & $-6.64 \mathrm{e}-07$ & .0000493 & -0.01 & 0.990 \\
\hline X4 & $-9.00 \mathrm{e}-06$ & .000017 & -0.53 & 0.619 \\
\hline X5 & -1.064653 & .8318002 & -1.28 & 0.257 \\
\hline X6 & -1.68087 & 1.96289 & -0.86 & 0.431 \\
\hline Gözlem Sayısı & 68 & & & \\
\hline Grup Sayısı & 6 & & & \\
\hline $\begin{array}{l}\text { Zaman } \\
\text { Periyodu }\end{array}$ & 13 & & & \\
\hline Hausman Testi & 29.20 & & & 0.0000 \\
\hline
\end{tabular}




\begin{tabular}{|l|l|l|l|l|}
\hline (Ki Kare) & & & & \\
\hline $\mathrm{R}^{2}$ (Aralık) & $(0,35-0,83)$ & Pesaran & 1.516 & 0.1295 \\
\hline Durbin-Watson & .7949908 & Wald & 396.69 & 0.0000 \\
\hline
\end{tabular}

$*, * *$ ve ${ }^{* * *}$ sırasıyla $\% 1, \% 5$ ve $\% 10$ anlam düzeyini ifade eder.

Regresyon sonuçlarına göre, faiz oranı $(X 1)$ ve döviz kuru (X2) değişkenleri gelişmiş ekonomilerde banka mevduatı/büyüme oranını etkileyen değişkenlerdir. Finansal gelişmişliği etkileyen makro değişkenleri tespit amacıyla kullanılan banka mevduatları/büyüme oranını etkileyen değişkenlerin dağılımı, çalışmada kullanılan iki farklı ülke grubu için tamamen farklı sonuçlar ortaya çıkarmıştır. Gelişmekte olan ekonomilerde, doğrudan yabancı sermaye yatırımları (LOGX3), cari denge (X4), büyüme oranlarının (X5) ve M2 para arzı (LOGX7); gelişmiş ekonomilerde ise faiz oranları (X1) ve döviz kurları (X2) değişkenleri banka mevduatları/büyüme oranını etkileyen faktörler şeklinde görülmüştür.

Tablo 15: Sonuçlar

\begin{tabular}{|l|l|l|}
\hline Finansal Gelişmişlik Göstergeleri & Ülke Grupları & Etkileyen Faktörler \\
\hline \multirow{2}{*}{ Borsa Endeksleri (Y1) } & Gelişmekte Olan Ekonomiler & $\mathrm{X} 1^{* *}$ \\
\cline { 2 - 3 } & Gelişmiş Ekonomiler & $\mathrm{X} 1^{* *}, \mathrm{X} 3^{* * *}, \mathrm{X} 5^{* *}, \mathrm{X} 6^{* * *}$ \\
\hline \multirow{2}{*}{$\begin{array}{l}\text { Finansal Piyasalar } \\
\text { Büyüklüğü/Büyüme Oranı (Y2) }\end{array}$} & Gelişmekte Olan Ekonomiler & $\mathrm{X} 1^{* *}, \mathrm{X} 2^{* *}, \mathrm{X} 4^{*}, \mathrm{X} 5^{* *}$ \\
\cline { 2 - 3 } $\begin{array}{l}\text { Banka Mevduatları/Büyüme Oranı } \\
\text { (Y3) }\end{array}$ & Gelişmiş Ekonomiler & $\mathrm{X} 1^{*}, \mathrm{X} 3^{* *}, \mathrm{X} 5^{* *}$ \\
\cline { 2 - 3 } & Gelişmekte Olan Ekonomiler & $\mathrm{LOGX3}{ }^{* *}, \mathrm{X} 4^{* * *}$ ve LOGX7 ${ }^{*}$ \\
\hline
\end{tabular}

${ }^{*}, * *$ ve ${ }^{* * *}$ sırasıyla \%1, \%5 ve \%10 seviyesinde istatistiksel anlamlılığı ifade etmektedir.

Not: Çalışmada kullanılan makro ekonomik değişkenler: X1 faiz oranı, X2 döviz kurları, X3 doğrudan yabancı sermaye yatırımları, X4 Cari denge, X5 büyüme oranları, X6 enflasyon, X7 M2 para arzıdır.

Tablo $15^{\prime}$ deki sonuçlara göre, her iki ülke grubunda da finansal gelişmişliği en fazla etkileyen değişken faiz oranlarıdır (X1). Daha sonra hem sayı, hem de önem düzeyi çerçevesinde etkileyiciler, doğrudan yabancı sermaye yatırımları (X3), büyüme oranları (X5) ve cari denge (X4) olarak devam etmiştir. Enflasyon (X6) ve M2 para arzı (X7) etkisi en az olan değişkenler olarak görülmüştür.

Gelişmekte olan ve gelişmiş ülke gruplarını karşılaştırdığımızda ise elde edilen sonuçlar şöyle özetlenebilir:

- Makro ekonomik değişkenlerin genel olarak finansal gelişmişliği temsilen çalışmada kullanılan borsa endeksleri (Y1), finansal piyasa büyüklüğü/büyüme oranları (Y2) ve banka mevduatları/büyüme oranı (Y3) değişkenlerini etkilediği görülmüştür.

- Makro ekonomik değişkenlerin finansal gelişmişlik göstergelerini etkilemeleri bakımından gelişmiş ve gelişmekte olan ülke grupları arasında belirgin farklılıkların olmadığı anlaşılmaktadır.

- Faiz oranı (X1), gelişmiş ekonomilerde finansal gelişmişlik göstergelerinin üçünü de etkileyen tek değişken olurken, gelişmekte olan ekonomilerde de aynı değişken en fazla etkileyicilik niteliğine sahip olmasına karşın sadece banka mevduatları/büyüme oranını etkilememiştir.

- Büyüme oranları (X5) ve doğrudan yabancı sermaye yatırımları (X3) değişkenleri finansal gelişmişliği etkileme nitelikleri yüksek sayılabilecek diğer değişkenlerdir.

- Döviz kuru (X2) her iki ülke grubunda da etkisi az görülen bir değişkendir. Cari işlemler (X4) değişkeni sadece gelişmekte olan ekonomilerde etkisi az görülen değişkendir.

- Enflasyon (X6) ve M2 para arzı (X7) değişkenleri ise etkileri en az olan değişkenler olduğu tespit edilmiştir.

\section{SONUÇ}

Finansal sistem, ekonomik aktörlerin pozisyonlarına istinaden fon transferlerinin yapıldığı piyasalardır. Küreselleşme olgusuna bağlı olarak günümüzde sermaye sınır tanımayan bir akışkanlığa ulaşmıştır. Günümüzde ekonomiler, küresel alanda dolaşan sermaye stokundan yararlanmak amacıyla ekonomik yapılarını yabancı sermaye girecek şekilde serbestleştirmektedirler. Ülke finansal piyasalarının derinleşmesiyle ortaya çıkan ekonomik yapı, aynı zamanda ülkelerin ekonomik kalkınmasının yanı sıra birçok ekonomik problemlerin 
çözülmesine de katkı sağlayabilmektedir. Finansal yapının derinleşmesi ve genişlemesi ise bir çok faktöre bağlı olmaktadır.

Bu çalışmada, finansal gelişmişliği etkileyen makro ekonomik faktörler gelişmiş (Model B'ler) ve gelişmekte olan ülkeler (Model A'lar) örnekleminde panel veri analizi ile tespit edilmeye çalışılmıştır. Analiz neticesinde genel olarak makro ekonomik değişkenlerin finansal gelişmişliği her iki ülke gurubunda da etkilediği, makro ekonomik değişkenler bakımından iki ülke gurubu arasında belirgin farklar olmadığı, bu değişkenler arasında en etkili değişkenin faiz oranları (X1) olduğu gözlemlenmiştir. Daha sonra ise etkileyicilik niteliği bulunan değişkenler doğrudan yabancı sermaye yatırımları (X3) ve büyüme oranları (X5) şeklindedir.

Granger nedensellik testinde ise panel regresyon analizine benzer sonuçlar elde edilmiştir. Gelişmekte olan ekonomilerde faiz oranı (X1) ve büyüme oranlarından (X5), borsa endekslerine (Y1) doğru ve doğrudan yabancı sermaye yatırımlarından (X3), piyasa büyüklüğü/büyüme oranına (Y2) doğru nedensellik görülmüştür. Gelişmiş ekonomilerde ise sadece doğrudan yabancı sermaye yatırımlarından (X3), borsa endekslerine doğru nedensellik olduğu tespit edilmiştir.

Finansal piyasaların gelişmesi ve derinleşmesi fon gereksinimi duyan ekonomik unsurların kaynak sağlama imkan ve koşullarını artırmaktadır. Maliyet, süre ve miktar gibi koşullar çerçevesinde daha uygun nitelikte fon sağlayan üretim, yatırım ve yönetsel kuruluşların ekonomik amaçlarını gerçekleştirmeleri de daha kolay olmaktadır. Bu çalışmada da görüldüğü üzere finansal piyasaların gelişmesinde başta faiz oranları olmak üzere ekonomik parametrelerin finansal gelişmişlik üzerine etkili olduğu görülmektedir. Bu bakımdan fon ihtiyacı olan birimlere daha uygun imkanlar sağlayan finansal gelişmişliğin sağlanabilmesi için politika yapıcılarının başta faiz oranları olmak üzere makro ekonomik parametrelere bu bakış açısıyla yaklaşmaları daha doğru ekonomik politikalar üretmelerine imkan sağlayacaktır.

Finansal gelişmişliğin fon talep edenlere daha iyi koşullar sağladığı düşünülürse, bundan sonraki çalışmalarda finansal piyasaların bu yönünün, finansal gelişmişlik göstergelerinin fon sağlamayla ilgili maliyet, süre ve miktar gibi özelliklerini etkileyip etkilemedikleri ile fon sağlayanların ekonomik amaçlarını gerçekleştirme üzerindeki etkilerinin araştırılması önerilmektedir.

\section{KAYNAKLAR}

Acaravci, S. K., Ozturk, İ. ve Acaravci, A. (2009). Financial Development and Economic Growth: Literature Survey and Empirical Evidence from Sub-Saharan African Countries. South African Journal of Economic and Management Sciences, 12(1), 11-27.

Acaravci, A., Ozturk, i. ve Acaravci, S. K. (2007). Finance-Growth Nexus: Evidence From Turkey. International Research Journal of Finance and Economics. 11, 30-40.

Acemoglu, D., Johnson, S., ve Robinson, J. A. (2001). The Colonial Origins Of Comparative Development: An Empirical İnvestigation. American Economic Review, 91, 1369-1401.

Acemoglu, D., Johnson, S., ve Robinson, J. A. (2002). Reversal Of Fortune: Geography And Institutions in The Making Of The Modern World Income Distribution. Quarterly Journal of Economics, 117, 1231-1294.

Achy, L. (2004). Financial Liberalization, Saving, Investment and Growth in MENA Countries. Middle East Economics, 6, 67-94. Aggarwal, R., Demirguc-Kunt, A. ve Peria, M. S. M. (2006). Do Workers Remittances Promote Financial Development? Policy Research Working Paper 3957. World Bank, Development Research Group.

Ağır, H. (2010). Türkiye'de Finansal Liberalizasyon ve Finansal Gelişme İlişkisinin Ekonometrik Analizi. Ankara: BDDK Kitapları No: 8.

Ağır, H., Peker, O. ve Kar, M. (2009). Finansal Gelişmenin Belirleyicileri Üzerine Bir Değerlendirme: Literatür Taraması. BDDK Bankacılık ve Finansal Piyasalar. 3 (2), 31-63.

Akçoraoğlu, A. (2000). Financial Sector and Economic Growth: En Exogeneity Analysis. Ankara Üniversitesi SBF Dergisi. 55, 1-25.

Akıncı, G. Y., Akıncı, M. ve Yılmaz, Ö. (2014). Finansal Gelişmişliğin Makroekonomik Belirleyicileri: Türkiye İçin Bir VAR Modeli. Uluslararası Alanya İşletme Fakültesi Dergisi. 6(1), 1-15.

Allen, F. ve Gale, D. (2000) Bubbles and Crises, Economic Journal. 110, 236-255. 
Allen, F. ve Gale, D. (1999) Bubbles, Crises, and Policy, Oxford Review of Economic Policy 15(3). 9-18.

Alptekin, V. (2012). Benoit Hipotezi: Seçilmiş OECD Ülkeleri Ölçeğinde Panel Veriler Yardımıyla Analizi. Celal Bayar Üniversitesi S.B.D. 10(2), 204-2015.

Ang, J. B. (2007). Are Financial Sector Policies Effective in Deepening the Malaysian Financial System? Monash University, Discussion Paper, http://www.buseco.monash.edu.au/eco/research/papers/2007/0207financeang.pdf ErişimTarihi 10.03.2016

Ang, J. B. ve McKibbin, W. J. (2005). Financial Liberalization, Financial Sector Development and Growth: Evidence from Malaysia. Brookıngs Discussion Papers In International Economıcs. No. 168

Arestıs, P. ve Demetrıades, P. (1997). Financial Development and Economic Growth: Assessing the Evidence, Economic Journal, 107 (442), 783-799.

Ayaydın, H.; Hayaloğlu, P. ve Baltacı, N. (2013). Hisse Senedi Piyasasının Gelişmesinin Makroekonomik ve Kurumsal Belirleyicileri Üzerine Bir Araştırma: Panel Veri Analizi. The Journal of Academic Social Science Studies. 6 (4), 125-142.

Bagehot, W. (1873). Lombard Street: A Description of the Money Market. London: Henry S. King.

Baltagi, B. H.; Demetriades, P. ve Law, S. H. (2007). Financial Development, Openness and Institutions: Evidence From Panel Data, Center for Policy Research Working Papers No.7.

http://www.worldeconomyandfinance.org/working_papers_publications/working_paper_PDFs/WEF0022.pdf Erişim Tarihi: 17.03.2016.

Beck, T. ve Levine, R. (2004). Stock Markets, Banks, and Growth: Panel Evidence. Journal of Banking \& Finance, 28, 423-442.

Beck, T.; Demirguc-Kunt, A., ve Levine, R. (2004). Finance, Inequality And Poverty: Cross-Country Evidence. NBER Working Paper 10979.

Boyd, J. H.; Levine, R. ve Smith, B. D. (2001). The Impact Of Inflation On Financial Sector Performance. Journal of Monetary Economics, 47, 221-248.

Calderon, C. ve Liu, L. (2002). The Direction of Causality Between Financial Development and Economic Growth. Central Bank of Chile, Working Papers No 184.

Ceylan, S. ve Durkaya, M. (2010). Türkiye'de Kredi Kullanımı - Ekonomik Büyüme Illişkisi. Atatürk Üniversitesi İktisadi ve İdari Bilimler Dergisi, $24(2), 21-35$.

Chang, T. (2002). Financial Development and Economic Growth in Mainland China: A Note on Testing Demand-Following or Supply-Leading Hypothesis. Applied Economics Letters, 9, 869-873.

Cherif, M. ve Kaouther, G. (2008). Macroeconomıc And Instıtutıonal Determinants Of Stock Market Development In Mena Region, The International Journal of Finance. 20 (4), 4987-5007.

Çakır Zeytinoğlu, F. (2007). İşletmelerin Dönen Varlıklarının Satışlar Üzerindeki Etkileri: En İyi Regresyon Yönteminin Seçimi ve Sektörel Karşılaştırma. Marmara Üniversitesi i.i.B.F. Dergisi. 23 (2), 331-349.

Doğan, H. (2008).Türkiye'de Finans ve Reel Ekonomi ilişkisi: Schumpeter Haklı mıydı? İktisat İşletme ve Finans. 23(272), 49-79.

Easterly, W., ve Levine, R. (1997). Africa's Growth Tragedy: Politics and Ethnic Divisions. Quarterly Journal of Economics, 112, 1203-1250.

Eschenbach, F. (2004), Finance and Growth: A Survey of the Theoretical and Empirical Literature Tinbergen Institute Discussion Paper, TI 2004039/2. http://papers.ssrn.com/sol3/papers.cfm?abstract id=530123 Erişim Tarihi: 17.03.2016.

Girma, S. ve Shortland, A. (2004). The Political Economy of Finansal Development. University of Liecester. Working Paper. No:04/21, July, 135.

Goldsmith, R. W. 1969. Financial Structure and Development, New Haven, CT: Yale University Press.

Hellman, T., Murdock, K., ve Stiglitz, J. (2000). Liberalization, Moral Hazard in Banking, and Prudential Regulation: Are Capital Requirements Enough? American Economic Review 90(1), 147-165.

Hicks, J. R, 1969. Automatists, Hawtreyans, and Keynesians. Journal of Money, Credit and Banking, 1(3), $307-317$.

Huang, Y. (2010). Determinants of Financial Development. Palgrave Macmillan, ISBN: 978-0-230-27367-2

Jalilian, H. ve Kirkpatrick, C. (2002). Financial Development and Poverty Reduction in Developing Countries. International Journal of Finance and Economics, 7, 97-108. 
Kaminsky, G. L. ve Schmukler, S. L. (2007). Short-Run Pain, Long-Run Gain: Financial Liberalization and Stock Market Cycles. IMF Working Paper. 07/34, 1-52.

Kar, M. (2001). Finansal Kalkınma ve Ekonomik Büyüme Arasındaki Nedensellik ilişkisi: Türkiye Örneği. Dokuz Eylül Üniversitesi, işletme Fakültesi Dergisi, 2 (2): 150-169.

Kaya, U. (2014). Menkul Kıymet Piyasaları Ekonomik Büyümenin Bir Dinamiği Midir? Gelişmiş ve Gelişmekte Olan Ülkelere Yönelik Panel Veri Analizi. Atatürk Üniversitesi I.i..B.F. Dergisi, 28 (4), 285-306. 